\title{
Carbon export in the naturally iron-fertilized Kerguelen area of the Southern Ocean based on the ${ }^{234} \mathrm{Th}$ approach
}

\author{
F. Planchon ${ }^{1}$, D. Ballas ${ }^{2}$, A.-J. Cavagna ${ }^{2}$, A. R. Bowie ${ }^{3,4}$, D. Davies ${ }^{4}$, T. Trull ${ }^{3,4,5}$, E. C. Laurenceau-Cornec ${ }^{3,4,5}$, P. Van \\ Der Merwe $^{4}$, and F. Dehairs ${ }^{2}$ \\ ${ }^{1}$ Laboratoire des Sciences de l'Environnement Marin (LEMAR), Université de Bretagne Occidentale, CNRS, IRD, UMR \\ 6539, IUEM; Technopôle Brest Iroise, Place Nicolas Copernic, 29280 Plouzané, France \\ ${ }^{2}$ Vrije Universiteit Brussel, Analytical, Environmental and Geo-Chemistry and Earth System Sciences, Brussels, Belgium \\ ${ }^{3}$ Institute for Marine and Antarctic Studies, University of Tasmania, Hobart, 7001, Australia \\ ${ }^{4}$ Antarctic Climate and Ecosystems Cooperative Research Centre, Hobart, 7001, Australia \\ ${ }^{5}$ CSIRO Marine and Atmospheric Research, Hobart, 7001, Australia
}

Correspondence to: F. Planchon (frederic.planchon@univ-brest.fr)

Received: 3 October 2014 - Published in Biogeosciences Discuss.: 25 November 2014

Revised: 30 March 2015 - Accepted: 16 April 2015 - Published: 23 June 2015

\begin{abstract}
This study examined upper-ocean particulate organic carbon (POC) export using the ${ }^{234} \mathrm{Th}$ approach as part of the second KErguelen Ocean and Plateau compared Study expedition (KEOPS2). Our aim was to characterize the spatial and the temporal variability of POC export during austral spring (October-November 2011) in the Fe-fertilized area of the Kerguelen Plateau region. POC export fluxes were estimated at high productivity sites over and downstream of the plateau and compared to a high-nutrient low-chlorophyll (HNLC) area upstream of the plateau in order to assess the impact of iron-induced productivity on the vertical export of carbon.

Deficits in ${ }^{234} \mathrm{Th}$ activities were observed at all stations in surface waters, indicating early scavenging by particles in austral spring. ${ }^{234} \mathrm{Th}$ export was lowest at the reference station R-2 and highest in the recirculation region (E stations) where a pseudo-Lagrangian survey was conducted. In comparison ${ }^{234} \mathrm{Th}$ export over the central plateau and north of the polar front (PF) was relatively limited throughout the survey. However, the ${ }^{234} \mathrm{Th}$ results support that Fe fertilization increased particle export in all iron-fertilized waters. The impact was greatest in the recirculation feature (3-4 fold at $200 \mathrm{~m}$ depth, relative to the reference station), but more moderate over the central Kerguelen Plateau and in the northern plume of the Kerguelen bloom ( 2-fold at $200 \mathrm{~m}$ depth).

The $\mathrm{C}$ : Th ratio of large $(>53 \mu \mathrm{m})$ potentially sinking particles collected via sequential filtration using in situ pumping
\end{abstract}

(ISP) systems was used to convert the ${ }^{234} \mathrm{Th}$ flux into a POC export flux. The $\mathrm{C}$ : Th ratios of sinking particles were highly variable $\left(3.1 \pm 0.1\right.$ to $\left.10.5 \pm 0.2 \mu \mathrm{mol} \mathrm{dpm}^{-1}\right)$ with no clear site-related trend, despite the variety of ecosystem responses in the fertilized regions. $\mathrm{C}: \mathrm{Th}$ ratios showed a decreasing trend between 100 and $200 \mathrm{~m}$ depth suggesting preferential carbon loss relative to ${ }^{234} \mathrm{Th}$ possibly due to heterotrophic degradation and/or grazing activity. $\mathrm{C}$ : Th ratios of sinking particles sampled with drifting sediment traps in most cases showed very good agreement with ratios for particles collected via ISP deployments ( $>53 \mu \mathrm{m}$ particles).

Carbon export production varied between $3.5 \pm 0.9$ and $11.8 \pm 1.3 \mathrm{mmol} \mathrm{m}^{-2} \mathrm{~d}^{-1}$ from the upper $100 \mathrm{~m}$ and between $1.8 \pm 0.9$ and $8.2 \pm 0.9 \mathrm{mmol} \mathrm{m}^{-2} \mathrm{~d}^{-1}$ from the upper $200 \mathrm{~m}$. The highest export production was found inside the PF meander with a range of $5.3 \pm 1.0$ to $11.8 \pm 1.1 \mathrm{mmol} \mathrm{m}^{-2} \mathrm{~d}^{-1}$ over the 19-day survey period. The impact of Fe fertilization is highest inside the PF meander with 2.9-4.5-fold higher carbon flux at $200 \mathrm{~m}$ depth in comparison to the HNLC control station. The impact of Fe fertilization was significantly less over the central plateau (stations A3 and E-4W) and in the northern branch of the bloom (station F-L) with 1.6-2.0fold higher carbon flux compared to the reference station $\mathrm{R}$. Export efficiencies (ratio of export to primary production and ratio of export to new production) were particularly variable with relatively high values in the recirculation feature (6 to $27 \%$, respectively) and low values (1 to $5 \%$, respectively) 
over the central plateau (station A3) and north of the PF (station F-L), indicating spring biomass accumulation. Comparison with KEOPS1 results indicated that carbon export production is much lower during the onset of the bloom in austral spring than during the peak and declining phases in late summer.

\section{Introduction}

Nutrient limitation is an essential control of upper-ocean productivity (Moore et al., 2013) and affects the associated uptake of carbon and its transfer to the deep ocean as sinking particulate organic matter. Attention has focused on iron $(\mathrm{Fe})$ as a limiting nutrient since the iron hypothesis of Martin (1990), who suggested that increased iron supply to the Southern Ocean (SO) during the last glacial maximum could have contributed to the drawdown of atmospheric $\mathrm{CO}_{2}$ by stimulating the oceanic biological pump. For the presentday ocean, iron limitation is now validated for several highnutrient low-chlorophyll (HNLC) regions, including the SO (Boyd et al., 2000, 2007; Coale et al., 2004; Martin et al., 1990, 1991; Sedwick et al., 1999; Smetacek et al., 2012). However, it is still under debate whether the positive growth response of phytoplankton due to iron addition results in enhanced export of biogenic particles and contributes to the long-term sequestration of carbon. This remains central to understanding the role of iron on the oceanic carbon cycle and ultimately on the past and future climate of the Earth.

Mesoscale iron addition experiments have revealed no clear trend in carbon export. Export fluxes estimated during Southern Ocean Iron RElease Experiment (SOIREE; polar waters south of Australia), the SOLAS air-sea gas exchange experiment (SAGE; subpolar waters south of New Zealand), European Iron Enrichment Experiment in the Southern Ocean (EisenEx; Atlantic polar waters) and IndoGerman iron fertilization experiment (LOHAFEX; South Atlantic waters) report no major differences between the $\mathrm{Fe}$ fertilized patch and the adjacent control site (Buesseler et al., 2005, 2004; Martin et al., 2013; Nodder et al., 2001). By contrast, the experiments SOFEX-South (polar waters south of New Zealand) and EIFEX (Atlantic polar waters south of Africa) showed increased vertical flux of particulate organic carbon (POC) due to iron addition (Buesseler et al., 2005; Jacquet et al., 2008; Smetacek et al., 2012). Enhanced export appears associated with experiments carried out (1) in high silicic acid waters south of the Antarctic polar front (PF) allowing fast-sinking, large diatoms to develop under low grazing pressure and (2) over a survey period sufficiently long to cover the time lag between the bloom development and the export event. However, the key results obtained with purposeful iron addition still differ and are difficult to scale up to regional and seasonal scales (Boyd et al., 2007).
Alternatives to short-term artificial experiments are the large and persistent phytoplankton blooms that develop annually in the vicinity of sub-Antarctic islands (Blain et al., 2007; Borrione and Schlitzer, 2013; Morris and Charette, 2013; Pollard et al., 2009) and close to the Antarctic continent (Alderkamp et al., 2012; Zhou et al., 2013) due to natural iron supply. These particular settings represent largescale natural laboratories, where the role of $\mathrm{Fe}$ on ecosystems ecology, productivity, structure, and associated export can be monitored over an entire seasonal cycle. Two previous important field studies were carried out in natural $\mathrm{Fe}$-fertilized areas: the CROZet natural iron bloom and EXport experiment (CROZEX, 2004-2005) (Pollard et al., 2009), and the KErguelen Ocean and Plateau compared study (KEOPS, 2005) (Blain et al., 2007). CROZEX studied the Crozet Islands region located in the sub-Antarctic waters of the Indian Ocean where a bloom occurs north of the islands in October/November followed by a secondary bloom in January. CROZEX results confirmed that the bloom is fueled with iron from Crozet Island (Planquette et al., 2007) and that phytoplankton uptake rates are much larger in the bloom area than in the HNLC control area (Lucas et al., 2007; Seeyave et al., 2007). For carbon export, the primary bloom results in a $\sim 3$ fold higher flux at the Fe-fertilized site than at the control site, and for the secondary bloom, no substantial differences are reported (Morris et al., 2007). Sinking particles collected by a neutrally buoyant sediment trap (PELAGRA) were dominated by diatom cells of various species and size indicating a pronounced contribution of primary producers to the export (Salter et al., 2007).

The second study (KEOPS) focused on the high productivity area of the Kerguelen Islands in the Indian sector of the SO. The Kerguelen bloom has two main features, a northern branch that extends northeast of the islands north of the PF (also called the plume), and a larger bloom covering $\sim 45000 \mathrm{~km}^{2}$ south of the PF and largely constrained to the shallow bathymetry of the Kerguelen Plateau $(<1000 \mathrm{~m})$ (Mongin et al., 2008). In austral summer 2004-2005, the bloom started in early November, peaked in December and January, and then rapidly declined in February (Blain et al., 2007). Fe fertilization over the plateau was demonstrated during KEOPS and attributed to vertical exchanges between the surface and the deep iron-rich reservoir existing above the plateau (Blain et al., 2008). The waters in the bloom showed higher biomass, greater silicate depletion, and important $\mathrm{CO}_{2}$ drawdown compared to the control site (Blain et al., 2007; Jouandet et al., 2008; Mosseri et al., 2008). Carbon export in the Fe-fertilized area in comparison to HNLC waters was 2-fold higher as estimated using the ${ }^{234} \mathrm{Th}$ proxy (Savoye et al., 2008), and 3-fold higher based on a seasonal dissolved inorganic carbon (DIC) budget (Jouandet et al., 2008). Direct observations of sinking particles using polyacrylamide gel traps indicates a dominant fraction of fecal pellets and fecal aggregates and suggests a strong influence of particle repackaging by grazers during the late stage of the Kergue- 
len bloom (Ebersbach and Trull, 2008). The unprecedented results obtained from CROZEX and KEOPS clearly highlight the crucial role of $\mathrm{Fe}$ in natural ecosystems and demonstrate the stimulation of the biological carbon pump in the $\mathrm{SO}$ resulting in an enhanced $\mathrm{CO}_{2}$ sink and carbon export at depth.

The KEOPS2 project was designed to improve the spatial and temporal coverage of the Kerguelen region. KEOPS2 was carried out in austral spring to document the early stages of the bloom and to complement results of KEOPS1 obtained in summer during the peak and decline of the bloom. The principal aims were to better constrain the mechanism of $\mathrm{Fe}$ supply to surface waters and to determine the response of ecosystems to Fe fertilization including the impact on vertical export of carbon. The sampling strategy covered two distinct areas: the principal bloom already investigated during KEOPS1 and located over the central plateau, and the plume downstream to the east of the islands and north of the PF.

In this study, we report upper-ocean POC export production estimated using the ${ }^{234}$ Th-based approach (Cochran and Masqué, 2003). POC fluxes at 100, 150, and $200 \mathrm{~m}$ depth were inferred from total ${ }^{234} \mathrm{Th}$ export fluxes estimated from ${ }^{234} \mathrm{Th}$ deficit in surface waters by applying the modeling approach of Savoye et al. (2006) for the ${ }^{234} \mathrm{Th}$ activity balance. ${ }^{234} \mathrm{Th}$ export fluxes were then converted into POC fluxes using POC $/{ }^{234} \mathrm{Th}$ ratio of large $(>53 \mu \mathrm{m})$ potentially sinking particles at the depth of export. Upper-ocean ${ }^{234} \mathrm{Th}$ and carbon export obtained in HNLC and Fe-enriched waters were used to assess the impact of natural fertilization on the vertical transfer of carbon. ${ }^{234} \mathrm{Th}$-derived fluxes were compared to free-drifting sediment and polyacrylamide gel trap data (Laurenceau-Cornec et al., 2015a). Using primary production estimates (Cavagna et al., 2014) we examine spatial and temporal variations in export efficiency during the survey. Finally, using KEOPS1 results, early and late bloom conditions are compared.

\section{Material and method}

\subsection{Study area and sampling strategy}

The KEOPS2 cruise took place between October and November 2011 on board the R/V Marion Dufresne. The studied region encompasses the Kerguelen Plateau located between Kerguelen and Heard islands, and the deeper offshore basin to the east of the islands (Fig. 1). Details of the large-scale circulation in this area can be found elsewhere (Park et al., 2008b). Briefly, the Kerguelen Plateau represents a major barrier to the eastward flow of the Antarctic Circumpolar Current (ACC). The ACC is divided into two branches with the most intense flow passing to the north of the islands and associated with the subantarctic front (SAF). The second branch is associated with the PF and passes south of the islands. When crossing the plateau, the southern branch turns

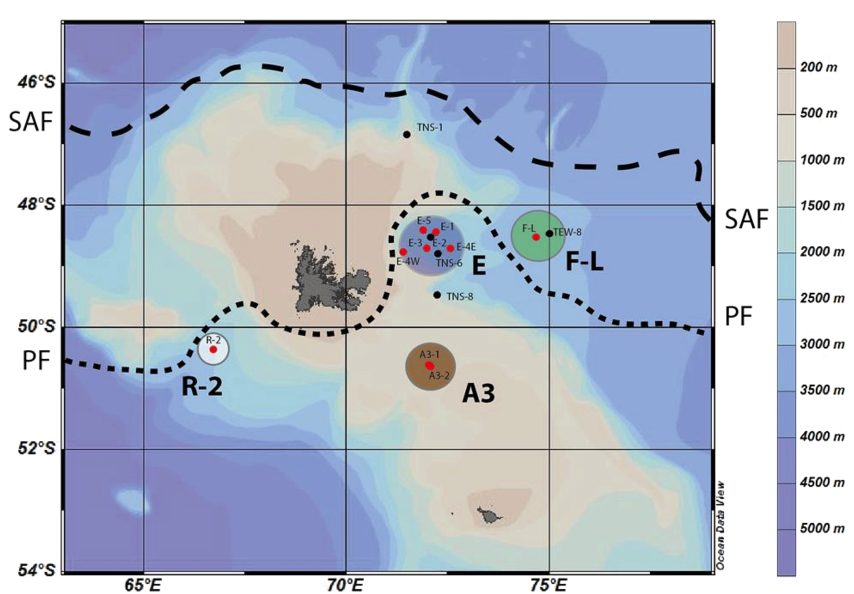

Figure 1. Stations map of ${ }^{234}$ Th measurements during the KEOPS2 expedition. Also, shown are the positions of the subantarctic front (SAF) and the PF adapted from Park et al. (2008b). Colored circles refer to the following clusters of stations showing similar characteristics: Control station R-2, north of the PF station F-L, plateau station A3, and PF meander E stations (see text for details).

back north and forms a large meander isolating a mesoscale recirculation structure south of the PF (Fig. 1).

The sampling strategy aimed at characterizing the spatial and the temporal variability of high productivity sites located on and off the plateau. The survey included two transects from south to north (TNS-1 to TNS-10) and from west to east (TEW-1 to TEW-8) for physics and stock parameters, and nine process stations (R-2, A3-1, A3-2, E-1, E-3, E-4W, E$4 \mathrm{E}, \mathrm{E}-5$, and F-L) where more intensive sampling including large-volume in situ filtration and sediment trap deployments were carried out. For this study, 14 stations were investigated including 5 transects stations (TNS-8, TNS-6, TNS-1, E-2, and TEW-8) sampled for total ${ }^{234} \mathrm{Th}$ activity and 9 process stations where total ${ }^{234} \mathrm{Th}$, particulate ${ }^{234} \mathrm{Th}$, and POC profiles obtained simultaneously allowed to estimate POC export production. Sediment traps deployed and successfully recovered at four process stations were also determined for ${ }^{234} \mathrm{Th}$ activity. Process stations were carried out in four distinct areas showing different characteristics (see Fig. 1):

- The reference station (R-2) was chosen in HNLC waters upstream of the islands in a non-Fe-fertilized area.

- The shallow central plateau was sampled at station A3, which corresponds to the plateau bloom reference station of KEOPS1. Station A3 was sampled twice (A31 and A3-2) over a period of 27.7 days (20 October16 November).

- The northern branch of the bloom, which develops north of the PF in the polar front zone (PFZ), was sampled at station F-L (6 November). 
- The recirculation feature in the PF meander (station E) received detailed attention with four successive visits (E-1, E-3, E-4E, and E-5) as part of a pseudoLagrangian time series over 19.6 days. In the same area, a highly productive station (E4W) located on the western edge of the recirculation feature and close to the jet of the PF was sampled but excluded from the pseudoLagrangian study.

\subsection{Total ${ }^{234}$ Th activities}

Total ${ }^{234} \mathrm{Th}$ activities were obtained from $4 \mathrm{~L}$ seawater samples collected from $12 \mathrm{~L}$ Niskin bottles. For transect stations, 13 depths were sampled between the surface and 20-90 m above the seafloor. For plateau station A3, samples were collected at 11 depths between the surface and $30-80 \mathrm{~m}$ above the seafloor. For deep stations (R, E-1, E-3, E-4E, E-4W, E$5, \mathrm{~F}-\mathrm{L}), 14$ depths were sampled between the surface and $900 \mathrm{~m}$, and two deep water samples (1000-2000 m) were systematically collected for calibration purposes (except at E$4 \mathrm{~W})$.

Seawater samples were processed for total ${ }^{234} \mathrm{Th}$ activity measurement following the double-spike procedure developed by Pike et al. (2005) and modified as per Planchon et al. (2013). Briefly, samples were acidified with nitric acid ( $\mathrm{pH} 2)$, spiked with ${ }^{230} \mathrm{Th}$ yield tracer, and left for 12 hours equilibration before co-precipitation with $\mathrm{MnO}_{2}$ (pH 8.5). Co-precipitated samples were filtered on highpurity quartz microfiber filters (QMA, Sartorius; nominal pore size $=1 \mu \mathrm{m} ; \varnothing 25 \mathrm{~mm}$ ), dried overnight and mounted on nylon filter holders covered with Mylar and Al foil for beta counting. Samples were counted twice on board using a low level beta counter (Risø, Denmark) and measurement was stopped when counting uncertainty was below $2 \%$ (RSD relative standard deviation). Residual beta activity was measured for each sample after a delay of six ${ }^{234} \mathrm{Th}$ half-lives ( $\sim 6$ months) and was subtracted from the gross counts obtained on-board.

After background counting, all samples were processed for ${ }^{234} \mathrm{Th}$ recovery using ${ }^{229} \mathrm{Th}$ as a second yield tracer and with a simplified procedure described elsewhere (Planchon et al., 2013). Briefly, $\mathrm{MnO}_{2}$ co-precipitates were dissolved in $10 \mathrm{ml}$ of an $8 \mathrm{M} \mathrm{HNO}_{3} / 10 \% \mathrm{H}_{2} \mathrm{O}_{2}$ solution, heated overnight, and filtered using Acrodisc $0.2 \mu \mathrm{m}$ syringe filters. Determination of ${ }^{230} \mathrm{Th} /{ }^{229} \mathrm{Th}$ ratios was carried out on high purity water diluted samples (10 to 20 times) by HR-ICP-MS (Element2, Thermo Scientific). The overall precision of ${ }^{230} \mathrm{Th} /{ }^{229} \mathrm{Th}$ ratio measurements was $1.8 \%$ (RSD) using triplicate samples and multiple standards analyzed over several analytical sessions. Average ${ }^{234} \mathrm{Th}$ recovery was $88 \pm 11 \%(n=200)$. Uncertainties of total ${ }^{234} \mathrm{Th}$ activity were estimated using error propagation law and represent $0.07 \mathrm{dpm} \mathrm{L}^{-1}$ on average. Standard deviation of the mean ${ }^{234} \mathrm{Th} /{ }^{238} \mathrm{U}$ ratio obtained for deep waters $(>1000 \mathrm{~m})$ was $0.03 \mathrm{dpm} \mathrm{L}^{-1}(n=19)$. ${ }^{238} \mathrm{U}$ activity $\left(\mathrm{dpm} \mathrm{L}{ }^{-1}\right)$ was calculated using the relationship
${ }^{238} \mathrm{U}( \pm 0.047)=(0.0786 \pm 0.0045) \times S-(0.315 \pm 0.158)$ (Owens et al., 2011).

\section{$2.3 \quad{ }^{234}$ Th flux}

${ }^{234}$ Th export fluxes were calculated using a 1-D box model, which accounts for total ${ }^{234} \mathrm{Th}$ mass balance. Detailed equations can be found elsewhere (Savoye et al., 2006). ${ }^{234} \mathrm{Th}$ export flux was estimated at 100,150 , and $200 \mathrm{~m}$ depth in order to account for (1) variations in the vertical distribution of ${ }^{234} \mathrm{Th}$ deficits and (2) total depth-integrated losses of ${ }^{234} \mathrm{Th}$ via export. This allows for comparison between stations at the same depth horizon, as well as with KEOPS1 study where a similar approach was used (Savoye et al., 2008). At all stations, ${ }^{234}$ Th flux was estimated under steady state (SS) assumption, i.e., considering constant total ${ }^{234} \mathrm{Th}$ activity over time and neglecting advective and diffusive flux of ${ }^{234} \mathrm{Th}$. For re-visited stations (A3 and E stations), ${ }^{234} \mathrm{Th}$ flux was also estimated under non-steady state (NSS) assumption. At A3, the NSS model was applied for the second visit with a time delay of 27.7 days. At E stations, NSS ${ }^{234}$ Th export flux was estimated when the time delay was greater than 1 week as recommended by Savoye et al. (2006). Consequently, the NSS calculation was carried out only at E-4E (14.6 days) and E-5 (19.6 days). The revisited stations E-2 and E-4W were not considered part of the pseudo-Lagrangian study at the $\mathrm{E}$ study site and were excluded from the NSS calculation.

In order to check the assumption that physical transport did not impact the ${ }^{234} \mathrm{Th}$ budget, the vertical diffusive flux $(\mathrm{Vz})$ was estimated using the vertical gradient of ${ }^{234} \mathrm{Th}$ activity and a range of vertical diffusivity coefficients (Kz values) between $10^{-4}$ and $10^{-5} \mathrm{~m}^{2} \mathrm{~s}^{-1}$ calculated from the Shih model (Park et al., 2014b). This range of $\mathrm{Kz}$ values for KEOPS2 is much lower than for KEOPS1 $\left(4 \times 10^{-4} \mathrm{~m}^{2} \mathrm{~s}^{-1}\right)$ obtained using the Osborn model (Park et al., 2008a). Vz was calculated using total ${ }^{234} \mathrm{Th}$ activities instead of the dissolved ${ }^{234} \mathrm{Th}$ (total ${ }^{234} \mathrm{Th}$-particulate ${ }^{234} \mathrm{Th}$ ) because of a poor vertical resolution of particulate ${ }^{234} \mathrm{Th}$ data in the first $200 \mathrm{~m}$. For all stations, the diffuse flux (Vz) estimated at 100, 150, and $200 \mathrm{~m}$ depth was always below $50 \mathrm{dpm} \mathrm{m}^{2} \mathrm{~d}^{-1}$ and represents a negligible contribution to the particle-associated export flux.

Lateral transport may also impact the ${ }^{234} \mathrm{Th}$ budget (Savoye et al., 2006) especially for stations located downstream of the Kerguelen Islands. From our data, this contribution cannot be quantified precisely, and is only qualitatively considered. Given the mean residence of surface water parcels over the plateau at station A3 (2-3 months) (Park et al., 2008b) or inside the recirculation feature (0.5-1 month) compared to the mean residence of ${ }^{234} \mathrm{Th}(\sim 1$ month), lateral contribution is likely to be minimal in these areas. Circulation at the northern station F-L is more dynamic and under the influence of northern Kerguelen shelf waters enriched in dissolved iron ( $\mathrm{dFe}$ ) (Quéroué et al., 2015). Shelf waters are probably depleted in ${ }^{234} \mathrm{Th}$ relative to ${ }^{238} \mathrm{U}$ due to the ear- 
lier development of the bloom in this area, as well as due to sediment resuspension and deposition (Savoye et al., 2008). However, water parcel trajectory calculations (d'Ovidio et al., 2015) suggest that shelf waters are transported in times of less than $0.5-1$ month to station F-L. This relatively short transit time still remains long enough for ${ }^{234} \mathrm{Th}$-poor waters to re-equilibrate with ${ }^{238} \mathrm{U}$ due to ${ }^{234} \mathrm{Th}$ in-growth, thus limiting a potential lateral component to the ${ }^{234} \mathrm{Th}$ export flux.

\subsection{Particulate ${ }^{234}$ Th and POC}

Suspended particulate matter was collected at nine process stations for particulate ${ }^{234} \mathrm{Th}$ and POC via large-volume (150-1000 L) in situ filtration systems (Challenger Oceanics and McLane WTS6-1-142LV pumps) equipped with $142 \mathrm{~mm}$ diameter filter holders. Two size classes of particles $(>53$ and $1-53 \mu \mathrm{m}$ ) were collected via sequential filtration across a $53 \mu \mathrm{m}$ mesh nylon screen (SEFAR-PETEX ${ }^{\circledR}$ ) and a $1 \mu \mathrm{m}$ pore size quartz fiber filter (QMA, Sartorius). To limit C and $\mathrm{N}$ blanks, the filters were pre-conditioned prior to sampling. For large particles ( $>53 \mu \mathrm{m})$, the PETEX screens were soaked in $\mathrm{HCl} 5 \%$, rinsed with Milli-Q water, dried at ambient temperature in a laminar flow hood, and stored in clean plastic bags. QMA filters were pre-combusted and acid cleaned following Bowie et al. (2010).

After collection, filters were subsampled under clean room conditions with acid cleaned ceramic scissors for PETEX screen and a $25 \mathrm{~mm}$ Plexiglas punch for QMA. For large particles, one-fourth of the $142 \mathrm{~mm}$ nylon screen was dedicated to ${ }^{234} \mathrm{Th}$ and POC. Particles were re-suspended in filtered seawater in a laminar flow clean hood and collected on $25 \mathrm{~mm}$ diameter silver ( $\mathrm{Ag})$ filters $(1.0 \mu \mathrm{m}$ porosity). For small particles, two $25 \mathrm{~mm}$ diameter punches were subsampled from the $142 \mathrm{~mm}$ QMA filters. Ag and QMA filters were dried overnight and mounted on nylon filter holders covered with Mylar and Al foil for beta counting. As for total ${ }^{234}$ Th activity, particulate samples were counted twice on board until the RSD was below $2 \%$. The procedure was similar for sediment traps samples. Sediment traps samples were re-suspended in filtered seawater, collected on Ag filters, dried, and mounted on nylon filter holder. Residual beta activity was measured in the home-based laboratory after six ${ }^{234}$ Th half-lives ( $\sim 6$ months) and was subtracted from the on-board measured values.

Following beta counting, particulate samples (QMA and Ag filters) were processed for POC measurement by an elemental analyzer - isotope ratio mass spectrometer (EAIRMS). Samples were dismounted from filters holders and fumed under $\mathrm{HCl}$ vapor for $4 \mathrm{~h}$ inside a glass desiccator to remove the carbonate phase. After overnight drying at $50^{\circ} \mathrm{C}$, samples were packed in silver cups and analyzed with a Carlo Erba NA 1500 elemental analyzer configured for C analysis and coupled on-line via a Con-Flo III interface to a Thermo Finnigan Delta V isotope ratio mass spectrometer. Acetanilide standards were used for calibration. $\mathrm{C}$ blanks were $1.46 \mu \mathrm{mol}$ for Ag filters and $0.52 \mu \mathrm{mol}$ for $25 \mathrm{~mm}$ QMA punch. Results obtained for two size-segregated POC fractions ( $>53$ and $1-53 \mu \mathrm{m}$ ) are reported in Appendix 2 along with particulate ${ }^{234}$ Th activity measured in the same samples.

\section{Results}

\section{1 $\quad{ }^{234}$ Th activity profiles}

The complete data set of total ${ }^{234} \mathrm{Th}\left({ }^{234} \mathrm{Th}\right.$ tot $),{ }^{238} \mathrm{U}$ activities $\left(\mathrm{dpm} \mathrm{L}{ }^{-1}\right)$, and associated ${ }^{234} \mathrm{Th} /{ }^{238} \mathrm{U}$ ratios can be found in Table $\mathrm{S} 1$ in the Supplement. At all stations, the deficit of ${ }^{234} \mathrm{Th}_{\text {tot }}$ relative to ${ }^{238} \mathrm{U}$ was observed in surface waters $\left({ }^{234} \mathrm{Th} /{ }^{238} \mathrm{U}=0.78-0.95\right) .{ }^{234} \mathrm{Th}_{\mathrm{tot}}$ activities increased progressively with depth and were back to equilibrium with ${ }^{238} \mathrm{U}$ at variable depths according to station: above $100 \mathrm{~m}$ at R, TNS-1, and F-L, between 100 and $150 \mathrm{~m}$ at A31, TEW-8, E-4E, and E-4W, and between 150 and $200 \mathrm{~m}$ at TNS-6, TNS-8, E-1, E-2, E-3, E-5, and A3-2. Such a pattern is typically encountered in the open ocean (Le Moigne et al., 2013) including the SO (Buesseler et al., 2001; Cochran et al., 2000; Morris et al., 2007; Planchon et al., 2013; Rutgers van der Loeff et al., 2011; Savoye et al., 2008) and indicate scavenging of ${ }^{234} \mathrm{Th}$ with sinking particles. In Fig. S1 in the Supplement, the early season trend in ${ }^{234} \mathrm{Th} /{ }^{238} \mathrm{U}$ ratios is presented along the south-to-north transect from the central plateau (first visit to A3, A3-1), on the downward slope of the plateau (TNS-8), across the E stations (TNS-6) to the warmer less-saline PFZ waters north of the PF (TNS-1). Surface ${ }^{234} \mathrm{Th} /{ }^{238} \mathrm{U}$ ratios varied from 0.92 (A3-1) to 0.85 (TNS-8) and indicates that export of particles had already occurred early for this time of the season (mid-October). Deficit was higher inside the PF meander $\left({ }^{234} \mathrm{Th} /{ }^{238} \mathrm{U}\right.$ ratios of 0.85 to 0.88 at TNS- 8 and TNS-6, respectively) and north of the PF $\left({ }^{234} \mathrm{Th} /{ }^{238} \mathrm{U}=0.88\right.$ at TNS-1) compared to the shallow central plateau $\left({ }^{234} \mathrm{Th} /{ }^{238} \mathrm{U}=0.92\right.$ at $\left.\mathrm{A} 3-1\right)$. Over the plateau, bottom water $(\sim 50-80 \mathrm{~m}$ above seafloor $)$ exhibited the lowest ${ }^{234} \mathrm{Th} /{ }^{238} \mathrm{U}$ ratios $(0.75)$. This pattern has already been documented (Savoye et al., 2008) and supports ${ }^{234}$ Th removal due to sediment re-suspension.

At process stations, ${ }^{234} \mathrm{Th}_{\text {tot }}$ profiles were obtained in combination with particulate ${ }^{234} \mathrm{Th}\left({ }^{234} \mathrm{Th}_{\mathrm{p}}\right)$ for two size fractions $(1-53 \mu \mathrm{m},>53 \mu \mathrm{m})$. Results obtained in the different areas are shown in Fig. 2 for ${ }^{234} \mathrm{Th}_{\mathrm{tot}},{ }^{234} \mathrm{Th}_{\mathrm{p}}$ (sum of the two size fractions, see Table S2), and dissolved ${ }^{234} \mathrm{Th}$ (total-particulate, ${ }^{234} \mathrm{Th}_{\mathrm{d}}$ ) along with ${ }^{238} \mathrm{U}$ activity (dpm $\mathrm{L}^{-1}$ ) deduced from salinity using the equation of Owens et al. (2011). The average ${ }^{234} \mathrm{Th}_{\text {tot }}$ within the first $100 \mathrm{~m}$ exhibited a relatively small variability over the KEOPS2 area with $2.21 \pm 0.10\left(n=4,{ }^{234} \mathrm{Th} /{ }^{238} \mathrm{U}=0.95 \pm 0.04\right)$ at $\mathrm{R}-$ $2,2.18 \pm 0.05\left(n=5,{ }^{234} \mathrm{Th} /{ }^{238} \mathrm{U}=0.93 \pm 0.02\right)$ at A3-1, $2.07 \pm 0.20\left(n=4,{ }^{234} \mathrm{Th} /{ }^{238} \mathrm{U}=0.89 \pm 0.08\right)$ at F-L, and $1.98 \pm 0.03 \mathrm{dpm} \mathrm{L}^{-1}\left(n=4,{ }^{234} \mathrm{Th} /{ }^{238} \mathrm{U}=0.84 \pm 0.01\right)$ at E-1. In contrast, surface ${ }^{234} \mathrm{Th}_{\mathrm{p}}$ activity, which reflects par- 

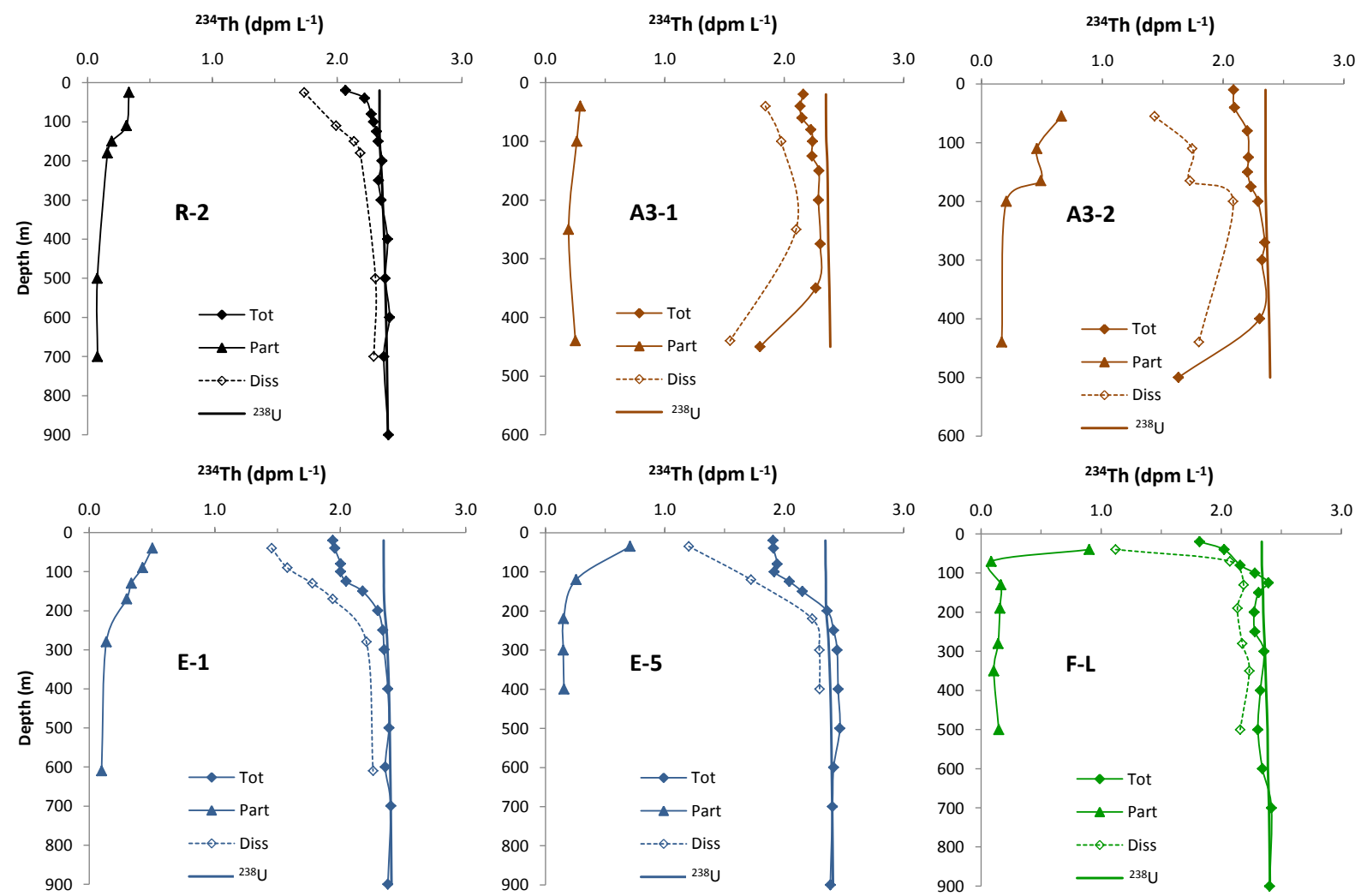

Figure 2. Depth profiles of total ${ }^{234} \mathrm{Th}\left({ }^{234} \mathrm{Th}\right.$ tot $)$, particulate ${ }^{234} \mathrm{Th}_{\mathrm{p}}$ (sum of the two size fractions), and dissolved ${ }^{234} \mathrm{Th}$ (total-particulate, $\left.{ }^{234} \mathrm{Th}_{\mathrm{d}}\right)$ activity $\left(\mathrm{dpm} \mathrm{L}{ }^{-1}\right)$ along with ${ }^{238} \mathrm{U}$ activity $\left(\mathrm{dpm} \mathrm{L}{ }^{-1}\right.$, solid lines) deduced from salinity at HNLC reference station R, central plateau station A3 (A3-1, first visit 20 October; A3-2, second visit 16 November), PF meander station E (E-1, first visit 30 October; E-5, fourth visit 8 November), and north of PF station F-L.

ticle concentration (Rutgers van der Loeff et al., 1997), was subject to larger variations. ${ }^{234} \mathrm{Th}_{\mathrm{p}}$ activity was low at $\mathrm{R}-2$ $\left(0.33 \mathrm{dpm} \mathrm{L}^{-1}\right)$ and at $\mathrm{A} 3-1\left(0.29 \mathrm{dpm} \mathrm{L}^{-1}\right)$, intermediate at E-1 $\left(0.50 \mathrm{dpm} \mathrm{L}^{-1}\right)$, and highest at F-L $\left(0.90 \mathrm{dpm} \mathrm{L}^{-1}\right)$. Over the course of the survey, averaged ${ }^{234} \mathrm{Th}_{\text {tot }}$ activity within the first $100 \mathrm{~m}$ remained remarkably stable over the plateau, with $2.13 \pm 0.06\left(n=3,{ }^{234} \mathrm{Th} /{ }^{238} \mathrm{U}=0.90 \pm 0.03\right)$ at $\mathrm{A} 3-2$ (27.7 days later), and in the PF meander, with $1.91 \pm 0.07$ $\left(n=4,{ }^{234} \mathrm{Th} /{ }^{238} \mathrm{U}=0.82 \pm 0.03\right)$ at E-3 (4.5 days later) and $1.92 \pm 0.02 \mathrm{dpm} \mathrm{L}^{-1}\left(\mathrm{n}=4,{ }^{234} \mathrm{Th} /{ }^{238} \mathrm{U}=0.82 \pm 0.01\right)$ at E-5 (19.6 days later). For the particulate phase, the situation was different. At $\mathrm{A} 3,{ }^{234} \mathrm{Th}_{\mathrm{p}}$ increased from 0.29 to $0.66 \mathrm{dpm} \mathrm{L}{ }^{-1}$ between the two visits. At site $\mathrm{E},{ }^{234} \mathrm{Th}_{\mathrm{p}}$ varied from 0.50 to $0.70 \mathrm{dpm} \mathrm{L}^{-1}$ between the first (E-1) and the last (E-5) visit, suggesting an increase in particle concentrations in surface waters at both $\mathrm{A} 3$ and $\mathrm{E}$ stations.

\section{$3.2{ }^{234}$ Th flux}

Total ${ }^{234} \mathrm{Th}$ activity profiles were used for estimating export fluxes based on SS and NSS assumptions. Cumulated export fluxes of total ${ }^{234} \mathrm{Th}$ are presented in Fig. 3 and Table S3. Using the SS calculation, ${ }^{234} \mathrm{Th}$ export from the first $100 \mathrm{~m}$ ranged from $412 \pm 134$ at R-2 to $1326 \pm 110 \mathrm{dpm} \mathrm{m}^{-2} \mathrm{~d}^{-1}$ at E-3. ${ }^{234} \mathrm{Th}$ export increased below $100 \mathrm{~m}$ depth except at station R-2 and north of the PF (stations F-L, TEW-8, and TNS-1) where ${ }^{234} \mathrm{Th}$ was back to equilibrium with ${ }^{238} \mathrm{U}$ above $100 \mathrm{~m}$. At $200 \mathrm{~m}$ depth, ${ }^{234} \mathrm{Th}$ export reached $993 \pm 200$ at A3-2, $1372 \pm 255$ at TNS-8, and between $1296 \pm 193$ and $1995 \pm 176 \mathrm{dpm} \mathrm{m}^{-2} \mathrm{~d}^{-1}$ at E stations. At A3, the NSS ${ }^{234}$ Th export was $736 \pm 186$ at $100 \mathrm{~m}$ and $1202 \pm 247 \mathrm{dpm} \mathrm{m}^{-2} \mathrm{~d}^{-1}$ at $200 \mathrm{~m}$ and compares well with SS export. At E stations, NSS export from the first $100 \mathrm{~m}$ were $911 \pm 242$ at E-4E and $1383 \pm 177 \mathrm{dpm} \mathrm{m}^{-2} \mathrm{~d}^{-1}$ at E-5 and also compares well with SS export. Between 100 and $200 \mathrm{~m}$, NSS ${ }^{234}$ Th export increased at E-5 $\left(2034 \pm 299 \mathrm{dpm} \mathrm{m}^{-2} \mathrm{~d}^{-1}\right)$ and decreased at E-4E $\left(520 \pm 402 \mathrm{dpm} \mathrm{m}^{-2} \mathrm{~d}^{-1}\right)$. In addition to water column data, export of ${ }^{234} \mathrm{Th}$ was determined from sediment traps deployed at $200 \mathrm{~m}$ depth (see Fig. 3 and Table 1). Details of trap deployments carried out at E-1, E-3, E-5, and A3-2 can be found elsewhere (Laurenceau-Cornec et al., 2015a). Export of ${ }^{234} \mathrm{Th}$ measured in trap samples ranged from $506 \pm 21$ at A3-2 to $1129 \pm 177 \mathrm{dpm} \mathrm{m}^{-2} \mathrm{~d}^{-1}$ at E-3 and represented $\sim 50 \%$ of the SS and NSS export determined from ${ }^{234} \mathrm{Th}_{\text {tot }}$ activity profiles. 

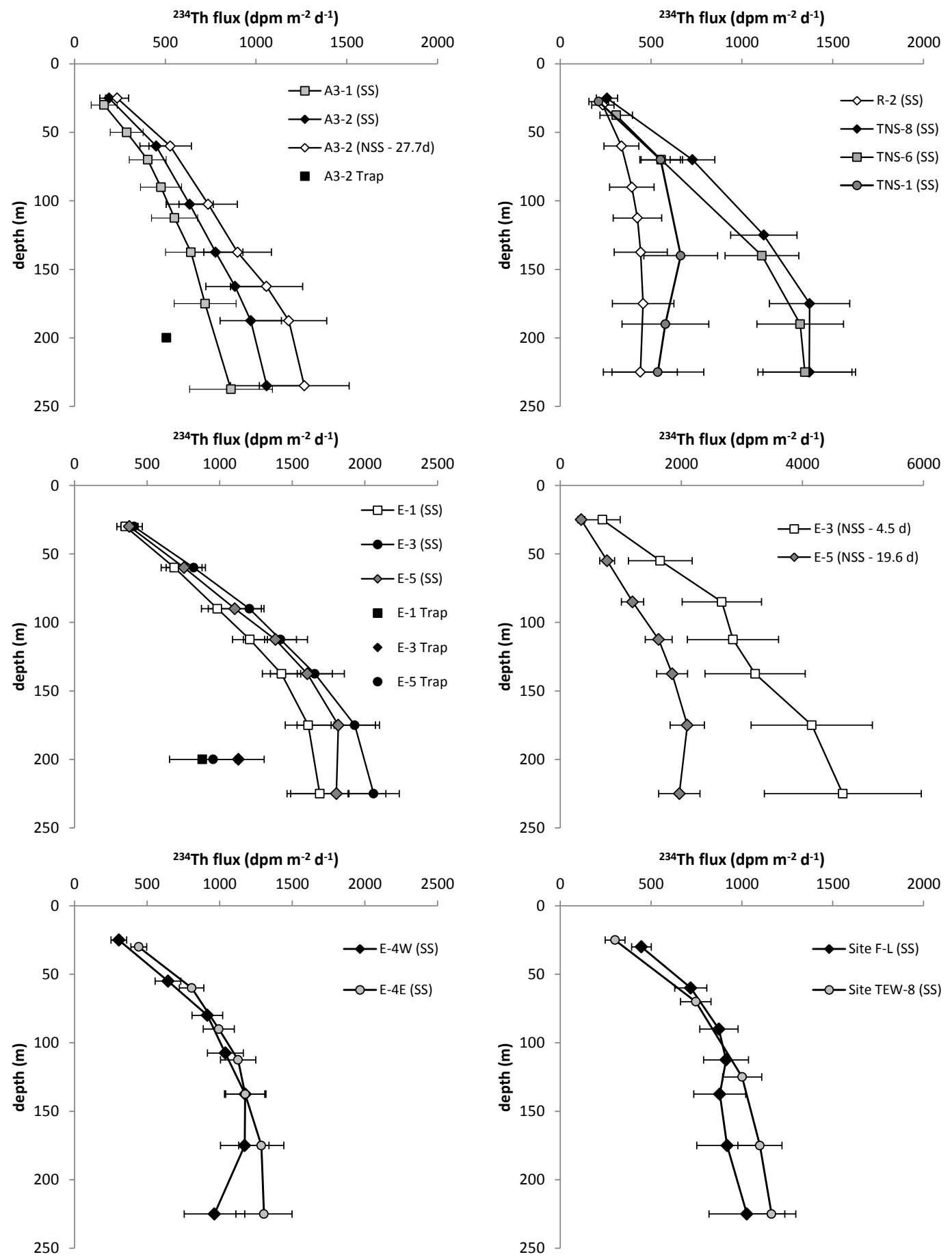

Figure 3. Depth profiles of cumulated total ${ }^{234}$ Th export fluxes from the surface to $250 \mathrm{~m}$ depth using steady state (SS) and non-steady state (NSS) models and comparison with ${ }^{234}$ Th export fluxes estimated from sediment traps at $200 \mathrm{~m}$.

\section{3 $\mathrm{C}$ : Th ratio of particles}

At process stations, particulate ${ }^{234} \mathrm{Th}$ activities and POC were obtained in two size fractions of particles $(1-53 \mu \mathrm{m}$, $>53 \mu \mathrm{m})$. Profiles of POC: ${ }^{234} \mathrm{Th}$ ratios $(\mathrm{C}: \mathrm{Th})$ are shown in Fig. 4. $\mathrm{C}$ : Th ratios were highly variable, ranging from 1.8 to 21.5 in $1-53 \mu \mathrm{m}$ particles and from 1.0 to 12.5 in $>53 \mu \mathrm{m}$ particles. For both size classes, $\mathrm{C}: \mathrm{Th}$ ratios were high in surface waters $(0-150 \mathrm{~m})$ with a range of 6.3-9.6 at $\mathrm{R}, 6.9-13.1$

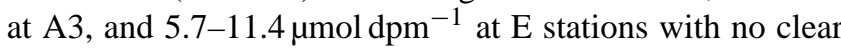
site-related trend. For open-ocean stations, $\mathrm{C}$ : Th ratios decreased rapidly with depth for the two size classes of particles 

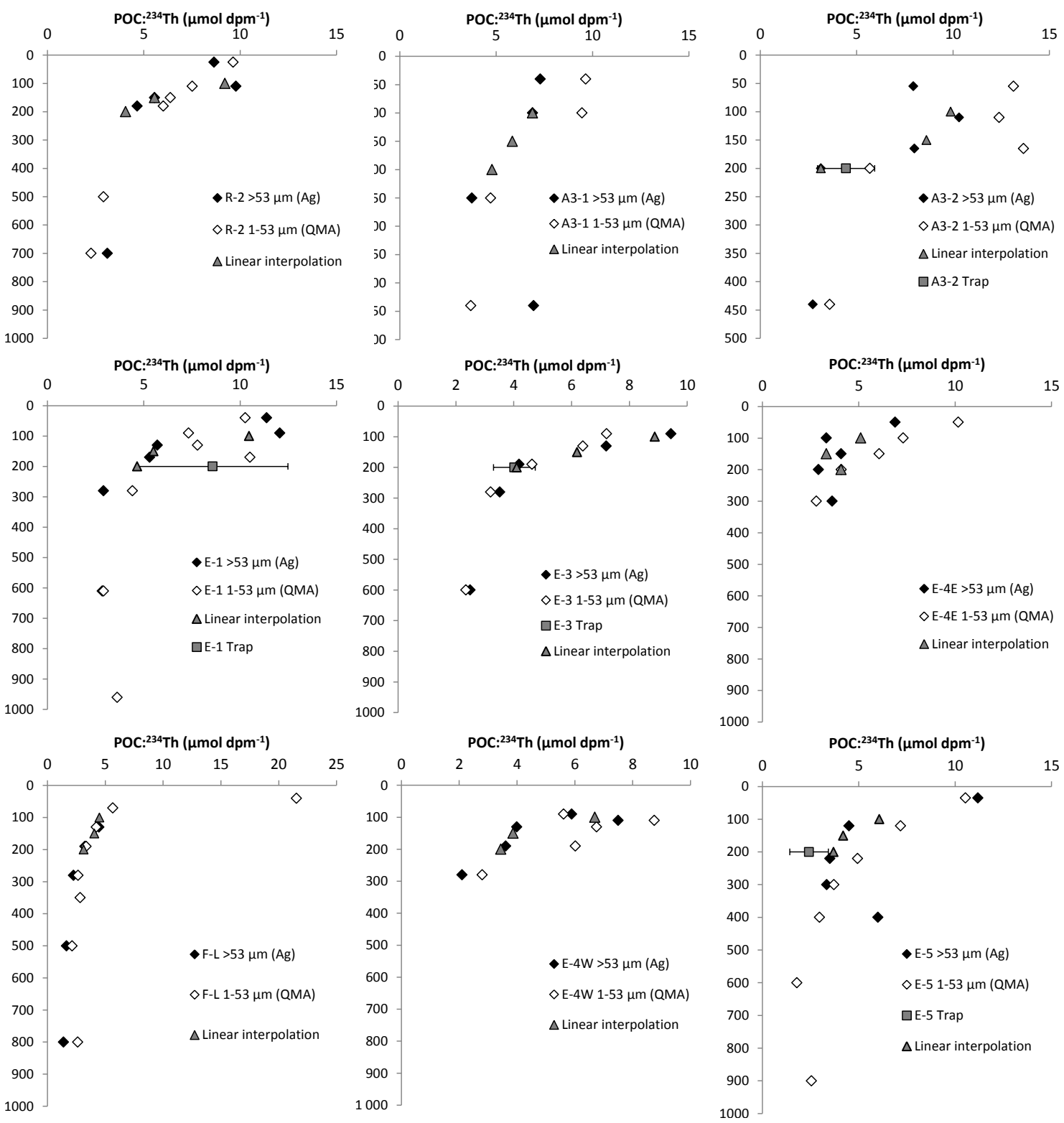

Figure 4. POC : ${ }^{234} \mathrm{Th}(\mathrm{C}: \mathrm{Th})$ ratio in size-fractionated $(1-53$ and $>53 \mu \mathrm{m})$ suspended particulate matter collected by ISP and comparison with sinking particles collected via sediment traps at $200 \mathrm{~m}$ depth. Also, shown is a linear interpolation of $\mathrm{C}$ : Th ratios at 100,150 , and $200 \mathrm{~m}$ depth for carbon flux estimates. Linear interpolation was obtained using a straight line fit between the upper and the lower data point relative to the target depth (i.e., 100, 150, and $200 \mathrm{~m}$ depth).

and reached relatively constant values in the mesopelagic zone with 2.8-4.8 at R-2, 2.6-4.5 at E stations, and 1.6$2.7 \mu \mathrm{mol} \mathrm{dpm}^{-1}$ at F-L. According to particle size, C: Th ratios showed different trends. At R-2, E-1, E-3, E-4W, and $\mathrm{E}-5, \mathrm{C}$ : Th ratios were comparable in small and large particles. At plateau stations A3-1 and A3-2, and to a lesser extent at E-4E, C: Th ratios increased with decreasing size of particles.

\section{4 $\mathrm{C}$ : Th ratio of sinking particles}

To estimate the POC export flux using the ${ }^{234}$ Th-based approach, the $\mathrm{C}$ : Th ratio of sinking particles needs to be determined at the depth of export (Buesseler et al., 1992). Assuming the larger particle size class to be representative of the sinking material (Buesseler et al., 2006), we used the $\mathrm{C}: \mathrm{Th}$ ratios of $>53 \mu \mathrm{m}$ particles to convert ${ }^{234} \mathrm{Th}$ fluxes into POC fluxes. C: Th ratios were estimated at fixed depths of 100 , 150 , and $200 \mathrm{~m}$, and results are listed in Table 1 and plotted in Fig. 4. For A3-1, A3-2, E-1, E-3, E-4W, and E-5, C:Th 
Table 1. ${ }^{234} \mathrm{Th}$ and POC export fluxes and C: Th ratios of sinking particles estimated at 100, 150, and $200 \mathrm{~m}$ depth, and carbon export efficiency (ThE and export production / new production (EP/NP) ratios) during KEOPS2 (bold text indicates that non-steady state calculations were used). ThE ratio defined as the ratio of POC export to net primary production (NPP) and EP/NP ratio defined as the ratio of POC export to new production (NP).

\begin{tabular}{|c|c|c|c|c|c|c|c|}
\hline Station & Date & $\begin{array}{r}\text { Depth } \\
(\mathrm{m})\end{array}$ & $\begin{array}{r}{ }^{234} \text { Th flux } \\
\left(\mathrm{dpm} \mathrm{m}^{-2} \mathrm{~d}^{-1}\right)\end{array}$ & $\begin{array}{r}\mathrm{C}: \mathrm{Th} \\
\left(\mu \mathrm{mol} \mathrm{dpm}{ }^{-1}\right)\end{array}$ & $\begin{array}{r}\text { POC flux } \\
\left(\mathrm{mmol} \mathrm{m}^{-2} \mathrm{~d}^{-1}\right)\end{array}$ & $\begin{array}{l}\mathrm{ThE} \\
(\%)\end{array}$ & $\begin{array}{r}\mathrm{EP} / \mathrm{NP} \\
(\%)\end{array}$ \\
\hline $\mathrm{R}-2$ & 25 Oct & 100 & $412 \pm 134$ & $9.2 \pm 0.5$ & $3.8 \pm 1.2$ & 34 & 73 \\
\hline $\mathrm{R}-2$ & $25 \mathrm{Oct}$ & 150 & $448 \pm 146$ & $5.6 \pm 0.4$ & $2.5 \pm 0.8$ & 22 & 48 \\
\hline $\mathrm{R}-2$ & 25 Oct & 200 & $449 \pm 203$ & $4.1 \pm 0.5$ & $1.8 \pm 0.9$ & 16 & 35 \\
\hline A3-1 & 20 Oct & 100 & $509 \pm 127$ & $6.9 \pm 0.7$ & $3.5 \pm 0.9$ & & \\
\hline A3-1 & 20 Oct & 150 & $666 \pm 140$ & $5.8 \pm 0.7$ & $3.9 \pm 0.9$ & & \\
\hline A3-1 & 20 Oct & 200 & $776 \pm 171$ & $4.8 \pm 0.5$ & $3.7 \pm 0.9$ & & \\
\hline A3-2 & $16 \mathrm{Nov}$ & 100 & $463 \pm 151$ & $9.9 \pm 0.1$ & $4.6 \pm 1.5$ & 3 & 3 \\
\hline A3-2 & $16 \mathrm{Nov}$ & 150 & $829 \pm 169$ & $8.6 \pm 0.1$ & $7.1 \pm 1.5$ & 5 & 5 \\
\hline A3-2 & 16 Nov & 200 & $993 \pm 200$ & $3.1 \pm 0.1$ & $3.1 \pm 0.6$ & 2 & 2 \\
\hline A3-2 trap & 15-17 Nov & 200 & $506 \pm 21$ & $4.5 \pm 1.5$ & $2.2 \pm 0.7$ & & \\
\hline A3-2 & 20 Oct-16 Nov & 100 & $736 \pm 186$ & $9.9 \pm 0.1$ & $7.3 \pm 1.8$ & 5 & 5 \\
\hline A3-2 & 20 Oct-16 Nov & 150 & $975 \pm 209$ & $8.6 \pm 0.1$ & $8.4 \pm 1.8$ & 5 & 5 \\
\hline A3-2 & 20 Oct-16 Nov & 200 & $1202 \pm 247$ & $3.1 \pm 0.1$ & $3.8 \pm 0.8$ & 2 & 2 \\
\hline F-L & $6 \mathrm{Nov}$ & 100 & $902 \pm 117$ & $4.5 \pm 0.4$ & $4.1 \pm 0.6$ & 1 & 2 \\
\hline F-L & $6 \mathrm{Nov}$ & 150 & $891 \pm 164$ & $4.1 \pm 0.4$ & $3.6 \pm 0.8$ & 1 & 1 \\
\hline F-L & $6 \mathrm{Nov}$ & 200 & $973 \pm 207$ & $3.1 \pm 0.5$ & $3.0 \pm 0.8$ & 1 & 1 \\
\hline E-1 & 30 Oct & 100 & $1111 \pm 120$ & $10.5 \pm 0.2$ & $11.6 \pm 1.3$ & 27 & 34 \\
\hline E-1 & 30 Oct & 150 & $1504 \pm 158$ & $5.5 \pm 0.2$ & $8.3 \pm 0.9$ & 19 & 24 \\
\hline E-1 & 30 Oct & 200 & $1665 \pm 201$ & $4.7 \pm 0.2$ & $7.7 \pm 1.0$ & 18 & 23 \\
\hline E-1 trap & 29 Oct $-3 \mathrm{Nov}$ & 200 & $881 \pm 226$ & $8.6 \pm 3.9$ & $7.0 \pm 2.3$ & & \\
\hline E-3 & $3 \mathrm{Nov}$ & 100 & $1326 \pm 110$ & $8.9 \pm 0.3$ & $11.8 \pm 1.1$ & 21 & 32 \\
\hline E-3 & $3 \mathrm{Nov}$ & 150 & $1742 \pm 142$ & $6.2 \pm 0.2$ & $10.8 \pm 0.9$ & 19 & 29 \\
\hline E-3 & $3 \mathrm{Nov}$ & 200 & $1995 \pm 176$ & $4.1 \pm 0.2$ & $8.2 \pm 0.8$ & 14 & 22 \\
\hline E-3 trap & 5-9 Nov & 200 & $1129 \pm 177$ & $4.0 \pm 0.7$ & $4.9 \pm 1.5$ & & \\
\hline E-4E & 13 Nov & 100 & $1051 \pm 121$ & $5.1 \pm 0.3$ & $5.4 \pm 0.7$ & 7 & 9 \\
\hline E-4E & 13 Nov & 150 & $1210 \pm 155$ & $3.3 \pm 0.1$ & $4.0 \pm 0.5$ & 5 & 7 \\
\hline E-4E & 13 Nov & 200 & $1296 \pm 193$ & $4.1 \pm 0.4$ & $5.3 \pm 1.0$ & 7 & 9 \\
\hline E-4E & 30 Oct-13 Nov & 100 & $911 \pm 242$ & $5.1 \pm 0.3$ & $4.6 \pm 1.3$ & 6 & 8 \\
\hline E-4E & 30 Oct-13 Nov & 150 & $726 \pm 315$ & $3.3 \pm 0.1$ & $2.4 \pm 1.0$ & 3 & 4 \\
\hline E-4E & 30 Oct-13 Nov & 200 & $525 \pm 402$ & $4.1 \pm 0.4$ & $2.1 \pm 1.7$ & 3 & 4 \\
\hline E-5 & 18 Nov & 100 & $1262 \pm 116$ & $6.1 \pm 0.1$ & $7.7 \pm 0.7$ & 10 & 14 \\
\hline E-5 & 18 Nov & 150 & $1671 \pm 153$ & $4.2 \pm 0.2$ & $7.0 \pm 0.7$ & 9 & 12 \\
\hline E-5 & $18 \mathrm{Nov}$ & 200 & $1810 \pm 190$ & $3.7 \pm 0.2$ & $6.7 \pm 0.8$ & 9 & 12 \\
\hline E-5 trap & 18-19 Nov & 200 & $955 \pm 546$ & $2.4 \pm 0.1$ & $2.0 \pm 1.0$ & & \\
\hline E-5 & 30 Oct-18 Nov & 100 & $1383 \pm 177$ & $6.1 \pm 0.2$ & $8.4 \pm 1.1$ & 11 & 15 \\
\hline E-5 & 30 Oct-18 Nov & 150 & $1928 \pm 235$ & $4.2 \pm 0.2$ & $8.1 \pm 1.0$ & 10 & 14 \\
\hline E-5 & 30 Oct-18 Nov & 200 & $2034 \pm 299$ & $3.7 \pm 0.2$ & $7.5 \pm 1.2$ & 10 & 13 \\
\hline E-4W & $11 \mathrm{Nov}$ & 100 & $1003 \pm 124$ & $6.7 \pm 0.2$ & $6.7 \pm 0.9$ & 3 & 3 \\
\hline E-4W & $11 \mathrm{Nov}$ & 150 & $1174 \pm 168$ & $3.9 \pm 0.1$ & $4.5 \pm 0.7$ & 2 & 2 \\
\hline E-4W & $11 \mathrm{Nov}$ & 200 & $1068 \pm 208$ & $3.4 \pm 0.2$ & $3.7 \pm 0.7$ & 2 & 2 \\
\hline
\end{tabular}

ratios of sinking particles were estimated from linear interpolation of measured $\mathrm{C}:$ Th ratios. At $\mathrm{R}-2$, the $\mathrm{C}: \mathrm{Th}$ ratio at $100 \mathrm{~m}$ represents the average ratio measured between 25 and $110 \mathrm{~m}$. At F-L, the $100 \mathrm{~m} \mathrm{C}:$ Th ratio was taken to be equal to the value at $130 \mathrm{~m}$. For E-4E, C:Th of large parti- cles were measured directly at the depths of 100,150 , and $200 \mathrm{~m}$ and were not interpolated. As illustrated in Fig. 4 and in Table $1, \mathrm{C}$ : Th ratios of sinking particles at $200 \mathrm{~m}$ estimated using ISP samples showed good agreement with sedi- 
ment trap data within uncertainty (3-6 and 18-46\% RSD for ISP and trap C: Th ratios, respectively) .

\subsection{POC export flux}

POC export fluxes were estimated at $100 \mathrm{~m}$ (EP100), $150 \mathrm{~m}$ (EP150), and $200 \mathrm{~m}$ (EP200) by multiplying the corresponding ${ }^{234} \mathrm{Th}$ export flux with the $\mathrm{C}: \mathrm{Th}$ ratio of sinking particles at the depth of export. Results are listed in Table 1. EP100 estimated with the SS model were lowest at A3-1 $\left(3.5 \pm 0.9 \mathrm{mmol} \mathrm{m}^{-2} \mathrm{~d}^{-1}\right)$ and at R-2 $\left(3.8 \pm 1.2 \mathrm{mmol} \mathrm{m}^{-2} \mathrm{~d}^{-1}\right)$ and highest at E1 with $11.8 \pm 1.3 \mathrm{mmol} \mathrm{m}^{-2} \mathrm{~d}^{-1}$. The EP100 at F-L was $4.1 \pm 0.6 \mathrm{mmol} \mathrm{m}^{-2} \mathrm{~d}^{-1}$ and was similar to the value for the control station R-2 and the plateau station A3. In the PF meander, EP100 remained stable between the two first visits (E3) with $11.8 \pm 1.1$, but decreased at the third visit (E-4E) to $5.4 \pm 0.7$ at E4-E, and increased to $7.7 \pm 0.7 \mathrm{mmol} \mathrm{m}^{-2} \mathrm{~d}^{-1}$ at the last visit (E-5). Station E-4W, not included in the time series, had an EP100 of $6.7 \pm 0.9 \mathrm{mmol} \mathrm{m}^{-2} \mathrm{~d}^{-1}$, very similar to E-4E on the eastern edge of the PF meander. At $200 \mathrm{~m}$, export fluxes ranged between $1.8 \pm 0.9$ (R-2) and $8.2 \pm 0.8 \mathrm{mmol} \mathrm{m}^{-2} \mathrm{~d}^{-1}$ (E-3). At the re-visited stations, carbon export was also estimated using the NSS model approach. NSS EP100 varied from 4.6 \pm 1.3 (E-4E) to $8.4 \pm 1.1 \mathrm{mmol} \mathrm{m}^{-2} \mathrm{~d}^{-1}$ (E-5). Within the uncertainty, NSS EP100 were similar (E-5 and E-4E) or higher (A3) in comparison to SS EP100. EP200 determined with the ${ }^{234} \mathrm{Th}$ proxy could be directly compared to fluxes estimated with sediment traps deployed at the same depth (Table 1). Trap fluxes in comparison to EP200 were in very good agreement within uncertainties at E-1 $(7.0 \pm 2.3$ and $7.7 \pm 1.0 \mathrm{mmol} \mathrm{m}^{-2} \mathrm{~d}^{-1}$ for trap and ${ }^{234} \mathrm{Th}$-based fluxes, respectively) and A3-2 (2.2 \pm 0.7 and $3.1 \pm 0.6 \mathrm{mmol} \mathrm{m}^{-2} \mathrm{~d}^{-1}$ for trap and ${ }^{234}$ Th-based fluxes, respectively), and 1.7-fold and 3.3-fold lower at E-3 and E-5, respectively.

\section{Discussion}

The principal aim of this study was to estimate how natural $\mathrm{Fe}$ fertilization affects carbon export at high productivity sites over and off-plateau during the early stages of the bloom. In the following sections, results obtained with the ${ }^{234}$ Th-based approach and summarized in Fig. 5 are discussed according to the four distinct zones investigated during the survey (control station R-2, north of the PF station F-L, plateau station A3, and PF meander E stations). For each zone, we briefly review the mode and timing of iron supply, described in more details elsewhere (Trull et al., 2015), deduced from dissolved and particulate iron inventories (Quéroué et al., 2015; van der Merwe et al., 2015) and from iron budgets in the surface mixed-layer (Bowie et al., 2015). We examine POC export efficiencies using two different metrics (Table 1): (1) ThE ratio defined as the ratio
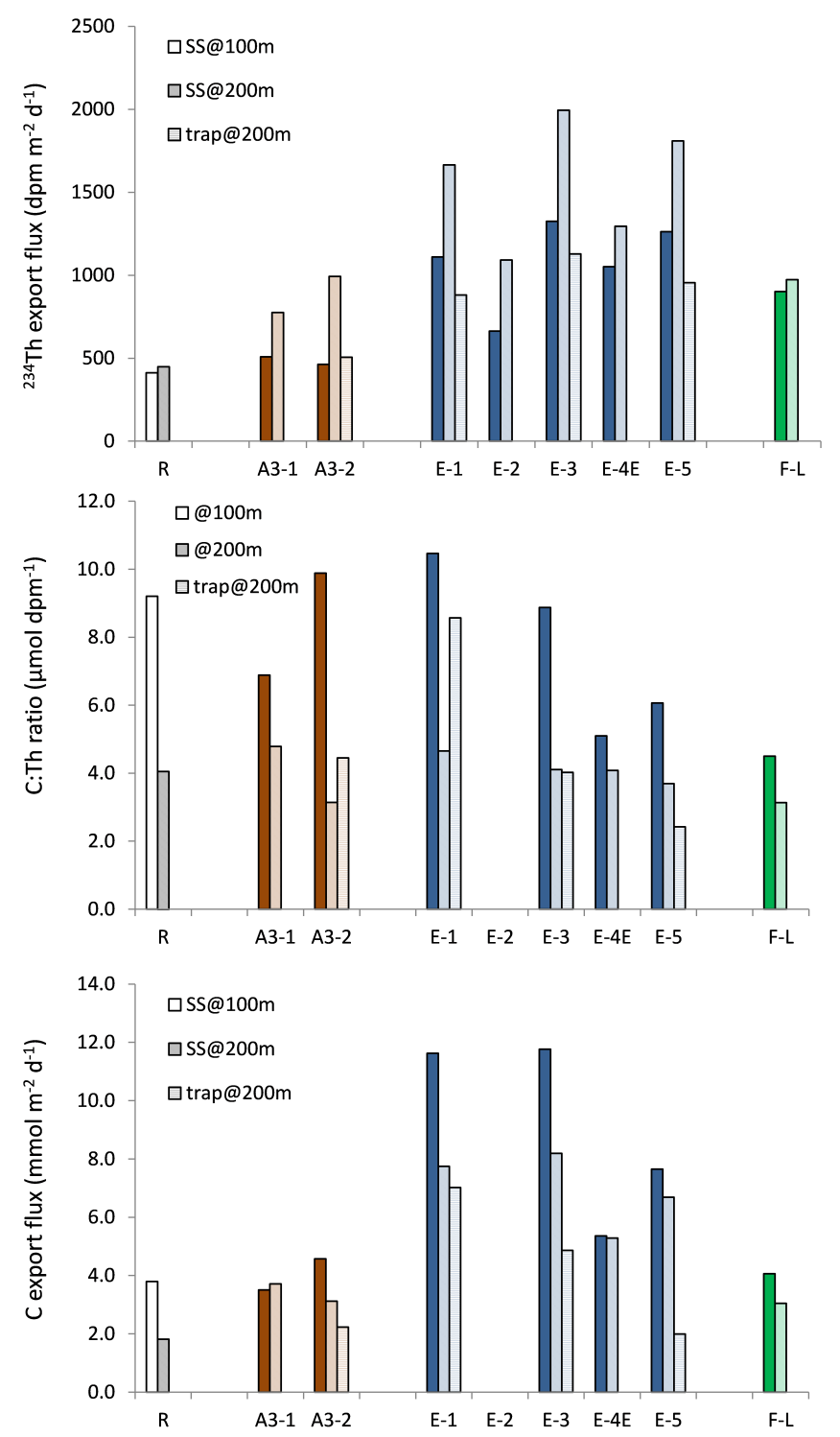

Figure 5. Summary results of ${ }^{234} \mathrm{Th}$ export fluxes $\left(\mathrm{dpm} \mathrm{m}^{-2} \mathrm{~d}^{-1}\right)$,

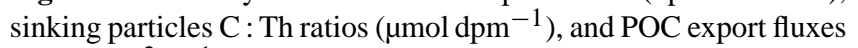
$\left(\mathrm{mmol} \mathrm{m}{ }^{-2} \mathrm{~d}^{-1}\right)$ obtained at 100 and $200 \mathrm{~m}$ depth and comparison with sediment trap data obtained at $200 \mathrm{~m}$ depth during KEOPS2 survey.

of POC export to net primary production (NPP) (Buesseler, 1998) and (2) EP / NP ratio estimated as the ratio between POC export to new production (NP) (Joubert et al., 2011; Planchon et al., 2013). NPP and NP are estimated from shortterm $(24 \mathrm{~h})$ deck board ${ }^{13} \mathrm{C}-\mathrm{HCO}_{3}^{-},{ }^{15} \mathrm{~N}-\mathrm{NO}_{3}^{-},{ }^{15} \mathrm{~N}-\mathrm{NH}_{4}^{+}$incubation experiments (Cavagna et al., 2014). NP, the fraction of $\mathrm{C}$ uptake supported by $\mathrm{NO}_{3}^{-}$assimilation, is estimated from the NPP and the f-ratio (Cavagna et al., 2014). NP is considered to provide an estimate of potentially "exportable production" based on a number of assumptions (Sambrotto 
and Mace, 2000) and despite several limitations (Henson et al., 2011).

\subsection{Reference site R-2}

At reference station R-2, the observed EP100 of $3.8 \pm 1.2 \mathrm{mmol} \mathrm{m}^{-2} \mathrm{~d}^{-1}$ is very small and reflects mainly a small and shallow export of ${ }^{234} \mathrm{Th}\left(412 \pm 134 \mathrm{dpm} \mathrm{m}^{-2} \mathrm{~d}^{-1}\right.$ at $100 \mathrm{~m}$ ). Low EP100 is consistent with the HNLC conditions at station R-2, where high concentrations of nitrate $(25 \mu \mathrm{M})$, silicic acid $(12-13 \mu \mathrm{M})$ (Blain et al., 2015), and very low biomass (Lasbleiz et al., 2014) are observed in surface waters. Dissolved iron $\left(<0.1 \mathrm{nmol} \mathrm{L}^{-1}\right)$ and particulate iron $(\mathrm{pFe})$ levels $\left(0.3 \mathrm{nmol} \mathrm{L}^{-1}\right)$ are also very low in surface waters (Quéroué et al., 2015; van der Merwe et al., 2015). Fluxes of $\mathrm{dFe}$ to the surface mixed layer are estimated to be very limited $\left(94 \mathrm{nmol} \mathrm{m}^{-2} \mathrm{~d}^{-1}\right)$ and essentially driven by vertical supplies (Bowie et al., 2015). Biomass at station R-2 appears to be dominated by small, slow-growing phytoplankton (Trull et al., 2015), which offer a limited potential for export. This feature is reflected in the partitioning of POC and ${ }^{234} \mathrm{Th}_{\mathrm{p}}$, with $\sim 90 \%$ being associated with the small $(1-53 \mu \mathrm{m})$ size fraction between 25 and $110 \mathrm{~m}$ depth. $\mathrm{C}:$ Th ratios of particles show no variation with particle size (Fig. 5) and suggest that large sinking particles may be a result of aggregation processes (Buesseler et al., 2006). This is supported by gel trap observations, revealing that phytodetrital aggregates are an important fraction of sinking material between 110 and $430 \mathrm{~m}$ depth (Laurenceau-Cornec et al., 2015a).

The flux obtained at the KEOPS2 reference station is similar to results obtained during the first leg of CROZEX (November-December 2004) at control sites M2 and M6, with carbon export of $4.9 \pm 2.7$ and $5.8 \pm 3.9 \mathrm{mmol} \mathrm{m}^{-2} \mathrm{~d}^{-1}$, respectively (Morris et al., 2007). Our value for $\mathrm{C}$ export is however much lower than the flux obtained in summer at the KEOPS1 control site C11 $\left(12.2 \pm 3.3 \mathrm{mmol} \mathrm{m}^{-2} \mathrm{~d}^{-1}\right.$; January-February 2005; Savoye et al., 2008) or during the second Leg of CROZEX (December 2004-January 2005) with $18.8 \pm 3.4$ at $\mathrm{M} 2$ and $14.4 \pm 3.0 \mathrm{mmol} \mathrm{m}^{-2} \mathrm{~d}^{-1}$ at M6 (Morris et al., 2007).

For the reference station R-2, ThE and EP/NP ratios were high with 34 and $73 \%$, respectively, and indicate a relatively efficient carbon pump despite the limited magnitude of carbon export and uptake (NPP $\left.=11.2 \mathrm{mmol} \mathrm{m}^{-2} \mathrm{~d}^{-1}\right)$. The ThE ratio falls in the range of most literature data for the $\mathrm{SO}$, which is generally elevated $(>10 \%)$ in HNLC waters (Buesseler et al., 2003; Savoye et al., 2008). During KEOPS1, a ThE ratio as high as $58 \%$ was observed at the reference station C11 (Savoye et al., 2008). The reasons for this high efficiency could be numerous, and a detailed discussion can be found elsewhere (Laurenceau-Cornec et al., 2015a). Briefly, efficient scavenging of POC at the low productivity site (R2) may be mediated by fast-sinking aggregates composed of heavily silicified diatoms. Although BSi levels are low
(Lasbleiz et al., 2014), this scenario is supported by the diatom community found at the reference station R-2, which was dominated by the heavily silicified Fragilariopsis spp. and Thalassionema nitzschioides (Laurenceau-Cornec et al., $2015 \mathrm{~b}$ and references therein). In addition, the limited zooplankton biomass at R-2 (Carlotti et al., 2015) and the rarity of fecal pellets in exported material (Laurenceau-Cornec et al., 2015a) suggest that attenuation/transformation of the POC flux through grazing is rather limited, and thus could also partly explain the high export efficiency at the reference station R-2.

With depth, carbon export decreased rapidly at station R2, and more than $50 \%$ of EP100 was lost between 100 and $200 \mathrm{~m}$ depth. Consequently, export efficiency decreased at $200 \mathrm{~m}$ depth to 16 and $34 \%$ based on the ThE and NP ratios, respectively. A similar trend was deduced from gel traps (Laurenceau-Cornec et al., 2015a). In our case, a sharp decrease of export with depth seems to be essentially driven by the $\mathrm{C}: \mathrm{Th}$ ratio of sinking particles, which decreases from 9.2 to $4.1 \mu \mathrm{mol} \mathrm{dpm}{ }^{-1}$ between 100 and $200 \mathrm{~m}$ (Fig. 4). Such a decrease may support a preferential loss of C relative to ${ }^{234} \mathrm{Th}$ due to a partial degradation of sinking particles (Buesseler et al., 2006). This feature could involve heterotrophic bacterial activity, since high content of bacteria cells $\left(2.9 \times 10^{5}\right.$ cell $\left.\mathrm{mL}^{-1}\right)$ are found between $100-150 \mathrm{~m}$ (Christaki et al., 2014).

\subsection{North of PF site (F-L)}

The northern PF station (F-L) exhibits moderate dFe enrichment in surface waters $\left(\sim 0.26 \mathrm{nmol} \mathrm{L}^{-1}\right)$ (Quéroué et al., 2015). Enrichment is much higher for $\mathrm{pFe}\left(1-2.5 \mathrm{nmol} \mathrm{L}^{-1}\right)$ presumably reflecting biological iron uptake and conversion into biogenic particulate fraction (van der Merwe et al., 2015). The iron budget is not available for station F-L so it is difficult to determine the mode of iron fertilization. However, $\mathrm{dFe}$ is likely to be supplied by both vertical exchanges with the Fe-rich reservoir from below and by lateral advection of iron-rich coastal waters from the northern Kerguelen shelf along the northern side of the PF jet (d'Ovidio et al., 2015; Park et al., 2014a; Trull et al., 2015). Analysis of drifter trajectories and altimetry-based geostrophic currents (d'Ovidio et al., 2015) indicate that advection of water parcels from the Kerguelen shelf is relatively short to station F-L ( 0.5 to 1 month). However, iron-rich waters rapidly disperse in this area and limit the persistence of iron fertilization (Trull et al., 2015).

EP100 at station F-L is low $\left(4.1 \pm 0.6 \mathrm{mmol} \mathrm{m}^{-2} \mathrm{~d}^{-1}\right)$ and is only 1.1-fold higher than at the control station R-2. This suggests no impact of Fe fertilization on upper-ocean carbon export in early bloom conditions. However, ${ }^{234} \mathrm{Th}$ export at F-L is 2.2 times higher in comparison to the reference station at the same depth, and indicates a more efficient scavenging of particles in the PFZ. This is supported further by the similar $100 \mathrm{~m}{ }^{234} \mathrm{Th}$ flux observed in the same area 
at TEW-8 $\left(886 \pm 162 \mathrm{dpm} \mathrm{m}^{-2} \mathrm{~d}^{-1}\right.$, see Table S3). It should be mentioned that EP100 at F-L may be underestimated because the $\mathrm{C}$ : Th ratio used to convert the ${ }^{234} \mathrm{Th}$ flux into $\mathrm{C}$ flux was taken at $130 \mathrm{~m}$ depth and may be lower than at $100 \mathrm{~m}$ depth. As an example, $\mathrm{C}: \mathrm{Th}$ ratio of $1-53 \mu \mathrm{m}$ particle at station F-L is 6.0 at $70 \mathrm{~m}$ and strongly decreases to $4.5 \mu \mathrm{mol} \mathrm{dpm}^{-1}$ at $130 \mathrm{~m}$. However, considering deeper export, EP200 at F-L $\left(3.0 \pm 0.8 \mathrm{mmol} \mathrm{m}^{-2} \mathrm{~d}^{-1}\right)$ appears 1.6fold higher than EP200 at the reference station R-2 suggesting an early impact of $\mathrm{Fe}$ fertilization on $\mathrm{C}$ export at this depth. In this area, EP200 estimated using the ${ }^{234}$ Th proxy shows excellent agreement with fluxes deduced from gel traps (Laurenceau-Cornec et al., 2015a).

The observed trend in EP drastically contrasts with the very high productivity at F-L. A massive bloom rapidly developed in early November in this area as revealed by satellite images (F. D'Ovidio, personal communication, 2014) and station F-L was visited only a few days after the start of the bloom. Phytoplankton biomass was high with total Chl $a$ up to $5.0 \mu \mathrm{g} \mathrm{L}{ }^{-1}$, total BSi up to 3.9 and POC up to $28.2 \mu \mathrm{mol} \mathrm{L}^{-1}$ (Lasbleiz et al., 2014), with the diatomdominated phytoplankton community in the fast-growing phase as revealed by Si (Closset et al., 2014) and C (Cavagna et al., 2014) uptake rates. The phytoplankton community was composed of a broad spectrum of size and taxa (Trull et al., 2015). Considering the three size fractions dominated by phytoplankton $(5-20,20-50,50-210 \mu \mathrm{m}), 48$ and $52 \%$ of POC was found above and below $50 \mu \mathrm{m}$, respectively, with small species presumably originating from Fe-rich waters of the northern Kerguelen shelf, and large species being characteristic of low biomass waters south of the PF offshore of the islands (Trull et al., 2015). It is interesting to note that the high biomass content is reflected in the partitioning of ${ }^{234} \mathrm{Th}$ showing very high ${ }^{234} \mathrm{Th}_{\mathrm{p}}$ activity $\left(0.9 \mathrm{dpm} \mathrm{L}^{-1}\right.$ at $40 \mathrm{~m}$, see Fig. 2). Furthermore, ${ }^{234} \mathrm{Th}_{\mathrm{p}}$ appears to be evenly distributed between small and large particles similarly to phytoplankton community structure. Between 40 and $70 \mathrm{~m}$ depth, $40 \%$ of ${ }^{234} \mathrm{Th}_{\mathrm{p}}$ is found with the small $(1-53 \mu \mathrm{m})$ particles and $60 \%$ with the large $(>53 \mu \mathrm{m})$ particles. This size spectrum of particles clearly offers higher potential for C export at F-L compared to the HNLC reference station.

However, comparison with NPP and NP reveals that export efficiency is very low at F-L with ThE and EP/NP ratios of 1 and $2 \%$, respectively. The two indicators clearly support an inefficient transfer of $\mathrm{C}$ to depth and indicate a pronounced decoupling between export and production. Observed decoupling may partly result from methodological mismatches in the measurements since time and space scales integrated by NPP and NP (24h incubation) differs from the ${ }^{234} \mathrm{Th}$ approach ( $\sim 1$ month). However, very low ThE and EP / NP ratios may also indicate that biomass is in an accumulation phase at station F-L and a major export event is likely to be delayed until later in the season. Such an accumulation scenario is supported by the small, fast-growing, and lesssilicified phytoplankton species observed at F-L (Trull et al.,
2015) which are presumably less efficient at exporting carbon to depth. Furthermore, high mesozooplankton biomass $\left(4.5 \mathrm{gC} \mathrm{m}^{-2}\right)$ (Carlotti et al., 2015) as well as the dominance of cylindrical fecal pellets in gel traps (Laurenceau-Cornec et al., 2015a) supports an intense grazing activity at F-L, which may contribute to the reduction of the POC flux and to the low export efficiency.

Comparison with literature data shows that EP100 at F-L $\left(4.1 \pm 0.6 \mathrm{mmol} \mathrm{m}^{-2} \mathrm{~d}^{-1}\right)$ remains substantially lower than POC export reported during CROZEX experiment both during leg 1 (range $4.9-17 \mathrm{mmol} \mathrm{m}^{-2} \mathrm{~d}^{-1}$ ) and leg 2 (13$30.0 \mathrm{mmol} \mathrm{m}^{-2} \mathrm{~d}^{-1}$ ), even though similar Fe-rich waters of the PFZ were sampled (Morris et al., 2007).

Attenuation of export production with depth is relatively weak at F-L, as only $25 \%$ of EP100 is lost between 100 and $200 \mathrm{~m}$ depth. This decrease is due to the decreasing $\mathrm{C}$ : Th ratio of sinking particles from 4.5 to $3.1 \mu \mathrm{mol} \mathrm{dpm}^{-1}$ between 130 and $200 \mathrm{~m}$. As already mentioned for the reference site, this trend may involve heterotrophic degradation of sinking particles. However, bacterial production at F-L is most intense in the first $60 \mathrm{~m}$ and decreases rapidly with depth to reach values similar to the reference station below $100 \mathrm{~m}$ depth (Christaki et al., 2014). At F-L, large particles seems to be more resistant to heterotrophic degradation and this may be linked to the higher abundance of fast-sinking cylindrical fecal pellets (Laurenceau-Cornec et al., 2015a).

\subsection{Plateau site A3}

Station A3 was located in iron- and silicic acid-rich waters over the central plateau and was visited twice, early (20 October) and late (16 November) in the survey. Surface mixed layer $\mathrm{dFe}$ levels were high at A3-1 $\left(0.28-0.32 \mathrm{nmol}^{-1} \mathrm{~L}^{-1}\right)$ and decreasing at $\mathrm{A} 3-2\left(0.14-0.18 \mathrm{nmol} \mathrm{L}^{-1}\right)$ probably due to biological uptake (Quéroué et al., 2015). Surface pFe exhibits a similar trend as $\mathrm{dFe}$, with higher concentrations at A3-1 compared to A3-2, but with a more important biogenic fraction at A3-2 (van der Merwe et al., 2015). Vertical $\mathrm{dFe}$ fluxes are by far the dominant sources of iron over the Plateau, and fuel the surface waters during episodic deepening of the upper mixed-layer (Bowie et al., 2015). Consequently, fertilization over the plateau is considered to be relatively recent, occurring during the maximum winter mixing period in August-September (Trull et al., 2015) and persisting over 2-3 months based on the estimated residence times of water parcels over the plateau (Park et al., 2008b).

EP100 over the plateau was very limited, with $3.5 \pm 0.9$ and $4.6 \pm 1.5 \mathrm{mmol} \mathrm{m}^{-2} \mathrm{~d}^{-1}$ at A3-1 and A3-2, respectively, based on the SS model. Based on the NSS model, EP100 at A3-2 appears slightly higher with $7.3 \pm 1.8 \mathrm{mmol} \mathrm{m}^{-2} \mathrm{~d}^{-1}$. EP100 at A3 shows no difference or a maximum of 1.9fold higher flux in comparison to the HNLC reference station R-2 suggesting limited impact of $\mathrm{Fe}$ fertilization. Interestingly, the ${ }^{234} \mathrm{Th}$ deficit follows the density structure and extends to the bottom of the mixed layer at $150-200 \mathrm{~m}$. 
This is much deeper than at stations R-2 or F-L, and consequently ${ }^{234} \mathrm{Th}$ export increases to $776 \pm 171$ at $\mathrm{A} 3-1$ and to $993 \pm 200 \mathrm{dpm} \mathrm{m}^{-2} \mathrm{~d}^{-1}$ at A3-2 between 100 and $200 \mathrm{~m}$ depth. At A3-2, POC flux was the highest at $150 \mathrm{~m}$ depth with EP150 of $7.1 \pm 1.5$ and of $8.4 \pm 1.8 \mathrm{mmol} \mathrm{m}^{-2} \mathrm{~d}^{-1}$ based on SS and NSS model respectively, and is 2.8-3.4fold higher in comparison to EP150 at the HNLC station. At $200 \mathrm{~m}$, increasing ${ }^{234} \mathrm{Th}$ export is canceled out by the simultaneous decrease of $\mathrm{C}$ : Th ratios resulting in low carbon export similar to A3-1. Comparison of PPS3/3 and gel sediment traps can be conducted at A3-2. First, we observe excellent agreement between ISP and PPS3/3 trap C:Th ratios (Fig. 5), indicating that the choice of large $(>53 \mu \mathrm{m})$ particles collected via ISP as representative of sinking particles was appropriate. Second, EP200 estimated in this study $\left(3.1 \pm 0.6\right.$ and $3.8 \pm 0.8 \mathrm{mmol} \mathrm{m}^{-2} \mathrm{~d}^{-1}$ with SS and NSS model, respectively) compare well with PPS $3 / 3$ trap flux $\left(2.2 \pm 0.7 \mathrm{mmol} \mathrm{m}^{-2} \mathrm{~d}^{-1}\right)$ and are smaller than gel trapderived fluxes $\left(5.5 \mathrm{mmol} \mathrm{m}^{-2} \mathrm{~d}^{-1}\right)$ (Laurenceau-Cornec et al., 2015a). The low flux collected with PPS $3 / 3$ traps may indicate under-trapping, but given that the trap was deployed only for 1 day, this site is particularly susceptible to temporal mismatch resulting from short-term variations in particle fluxes. However, it is worth mentioning that the good agreement found between the different and totally independent approaches is encouraging and tends to confirm that export production over the central plateau was rather low throughout the survey.

Low export at A3 contrasts with the rapid biomass increase that occurred a few days before the second visit as revealed by satellite images (F. D'Ovidio, personal communication, 2014). The phytoplankton bloom at $\mathrm{A} 3$ showed different characteristics compared to station F-L, suggesting variable biological responses to $\mathrm{Fe}$ fertilization. The bloom over the central plateau was dominated by fast-growing, large, and heavily silicified diatoms (Trull et al., 2015) showing very high Si uptake rates (Closset et al., 2014). The change in biomass levels at $\mathrm{A} 3$ is well reproduced by ${ }^{234} \mathrm{Th}_{\mathrm{p}}$ activity which increases from 0.25 to $0.55 \mathrm{dpm} \mathrm{L}^{-1}$ between the first and the second visit. These changes are observed also in the size partitioning of ${ }^{234} \mathrm{Th}_{\mathrm{p}}$. While at A3-1, $95 \%$ of ${ }^{234} \mathrm{Th}_{\mathrm{p}}$ is found to be associated with small $(1-53 \mu \mathrm{m})$ particles, at A3-2 $\sim 70 \%$ is found to be associated with large $(>53 \mu \mathrm{m})$ particles between 55 and $165 \mathrm{~m}$ depth. This clearly suggests a very high potential for export at A3-2, although the massive export event had not yet commenced. Delayed export is suggested further by the very low ThE and EP/NP ratios at $100 \mathrm{~m}$ depth of 3 and $5 \%$, respectively, at A3-2, which indicates that biomass was accumulating in the mixed layer.

Over the central plateau, EP200 during the early stages of the bloom (range of $3.1 \pm 0.6-3.8 \pm 0.8 \mathrm{mmol} \mathrm{m}^{-2} \mathrm{~d}^{-1}$ ) are 4.4 to 12 times smaller than during the KEOPS1 late summer condition at the same depth horizon (13.9 \pm 5.9 $37.7 \pm 13.3 \mathrm{mmol} \mathrm{m}^{-2} \mathrm{~d}^{-1}$ ) (Savoye et al., 2008). This difference is essentially due to much higher ${ }^{234} \mathrm{Th}$ fluxes reported during KEOPS1 (range 2249 $\pm 772-$ $8016 \pm 949 \mathrm{dpm} \mathrm{m}^{-2} \mathrm{~d}^{-1}$ ), indicating that particle scavenging is much more intense in January-February during the peak and decline of the bloom. Interestingly, the $\mathrm{C}: \mathrm{Th}$ ratio of sinking particles exhibits a similar range over the entire growth season, 3.1-9.9 during KEOPS1 and 4.7-7.7 $\mu \mathrm{mol} \mathrm{dpm}^{-1}$ during KEOPS-2, between 100 and $200 \mathrm{~m}$ depth. This is relatively surprising because sinking particles are very different between the early and late bloom period over the plateau. During KEOPS2, sinking particles were dominantly composed of phytodetrital aggregates (Laurenceau-Cornec et al., 2015a), and rapid aggregation of diatom cells was also evidenced from underwater vision profiler observations and modeling (Jouandet et al., 2014). During KEOPS1, the export process was different and the majority of the particle flux (composed of fecal pellets and fecal aggregates) was processed through the heterotrophic food web (Ebersbach and Trull, 2008).

\subsection{PF meander site E}

Export in the recirculation feature south of the PF (E stations) was the highest for the whole survey (Fig. 5). The four visits carried out as a pseudo-Lagrangian survey (E-1, E-3, E-4E, and E-5) revealed the short-term temporal variability of carbon export over 19.6 days. Surface waters in this area show low-to-moderate enrichment in $\mathrm{dFe}$ levels relative to the reference station R-2 but with a high variability (range of 0.06$0.38 \mathrm{nmol} \mathrm{L}^{-1}$ ) (Quéroué et al., 2015). Mode and timing of iron fertilization appears to be complex in the PF meander and differs from over the plateau. The iron budgets suggest that lateral supplies of $\mathrm{dFe}$ are the dominant sources of iron for the recirculation feature (4-5-fold greater than the vertical flux) (Bowie et al., 2015). Based on water parcel trajectories, the recirculation region could be fueled with Fe-rich waters from the northern Kerguelen shelf, similarly to the north of PF region (station F-L) but delayed. Also, waters derived from northeast are diluted with waters derived from the south (d'Ovidio et al., 2015; Park et al., 2014a). Thus, fertilization of the recirculation region is likely to be less recent and less intense than at station F-L, but is probably more persistent (Trull et al., 2015).

EP100 was particularly elevated at the first $\left(11.6 \pm 1.3 \mathrm{mmol} \mathrm{m}^{-2} \mathrm{~d}^{-1}, \quad \mathrm{E}-1\right)$ and second visit $\left(11.8 \pm 1.1 \mathrm{mmol} \mathrm{m}^{-2} \mathrm{~d}^{-1}, \mathrm{E}-3\right)$, decreased at the third visit $\left(5.4 \pm 0.7 \mathrm{mmol} \mathrm{m}^{-2} \mathrm{~d}^{-1}\right.$, E-4E), and then increased again during the fourth visit $\left(7.7 \pm 1.3 \mathrm{mmol} \mathrm{m}^{-2} \mathrm{~d}^{-1}\right.$, E-5). A comparison with the reference station indicates 1.4-3-fold enhanced export (at $100 \mathrm{~m}$ ) within the recirculation feature suggesting an early impact of Fe fertilization. High EP100 appears primarily influenced by an elevated $100 \mathrm{~m}{ }^{234} \mathrm{Th}$ export, ranging between $1051 \pm 121$ and $1326 \pm 110 \mathrm{dpm} \mathrm{m}^{-2} \mathrm{~d}^{-1}$. Note that high ${ }^{234} \mathrm{Th}$ export was also observed in the same area earlier in the survey (21-22 October) at transect stations TNS-6 and TNS-8 (see 
Table S3). These results support an early export event in the PF meander that had occurred before the start of the bloom and was associated with moderate biomass levels. The integrated total Chl $a$ stocks at $200 \mathrm{~m}$ were relatively stable with 141 at E-1, 112 at E-2, 96 at E-3, 108 at E-4E, and $126 \mathrm{mg} \mathrm{m}^{-2}$ at E-5 (Closset et al., 2014). Furthermore, the relatively constant ${ }^{234} \mathrm{Th}$ flux over the 19-day period may indicate that particle scavenging is at steady state, i.e., constant export (Savoye et al., 2006). This is supported also by the excellent agreement found between SS and NSS estimates of $100 \mathrm{~m}{ }^{234} \mathrm{Th}$ fluxes at E-4E and E-5 (Table 1). However, local variation in ${ }^{234} \mathrm{Th}$ distribution seems to exist in the PF meander as seen with the smaller ${ }^{234} \mathrm{Th}$ flux recorded at station E-2 which was part of the west-to-east transect (TEW, Table S3 and Fig. 5). The smaller deficit at this station may have been caused by lateral advection of ${ }^{234}$ Th-rich (lower deficit) waters originating from the jet of the PF passing to the north. The second controlling factor of EP100 was the sinking particles $\mathrm{C}: \mathrm{Th}$ ratio, showing elevated values at E-1 $\left(10.5 \pm 0.2 \mu \mathrm{mol} \mathrm{dpm}^{-1}\right)$

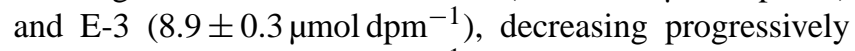
at E-4E $\left(5.1 \pm 0.3 \mu \mathrm{mol} \mathrm{dpm}^{-1}\right)$, and increasing again at E-5 $\left(6.1 \pm 0.2 \mu \mathrm{mol} \mathrm{dpm}^{-1}\right)$. As already mentioned, such a decrease may indicate preferential loss of carbon relative to ${ }^{234} \mathrm{Th}$ (Buesseler et al., 2006). This may involve food web interactions including bacterial production in the mixed layer increasing from 30 (E-1) to $54.7 \mathrm{nmol} \mathrm{C} \mathrm{L}^{-1} \mathrm{~d}^{-1}$ (E-5) (Christaki et al., 2014) and grazing activity by zooplankton (Carlotti et al., 2015).

EP200 was also elevated in the recirculation feature (range of $5.3 \pm 1.0$ to $8.2 \pm 0.8 \mathrm{mmol} \mathrm{m}^{-2} \mathrm{~d}^{-1}$ ) but shows less temporal variability. High EP200 results from a very deep ${ }^{234} \mathrm{Th}$ deficit extending down to $200 \mathrm{~m}$ depth, except at E-4E where the export depth (depth at which ${ }^{234} \mathrm{Th}$ is to back equilibrium with $\left.{ }^{238} \mathrm{U}\right)$ is shallower $(\sim 150 \mathrm{~m})$. Consequently, important increases in ${ }^{234} \mathrm{Th}$ export (up to a factor of 2 at E-5) were observed between 100 and $200 \mathrm{~m}$ depth. This feature is not in line with the relatively shallow mixed layer depth estimated in the PF meander (range of 38 to $74 \mathrm{~m}$ depth) and seems to follow the depth of the winter mixed layer. Note that macronutrients (nitrate and silicic acid) and dissolved trace elements profiles (Quéroué et al., 2015) display similar patterns to the ${ }^{234} \mathrm{Th}$ deficit. Such a vertical distribution suggests important vertical mixing in the area and tends to confirm that ${ }^{234} \mathrm{Th}$ export has occurred earlier in the survey. The ${ }^{234} \mathrm{Th}$ export at $200 \mathrm{~m}$ displays little variability over the 19.6 days of sampling and this feature is also observed in sediment traps deployed at E-1, E-3, and E-5, even though the traps have collected $\sim 50 \%$ of the flux deduced from the ${ }^{234} \mathrm{Th}$ deficit. The $\mathrm{C}: \mathrm{Th}$ ratio in sinking particles decreases sharply between 100 and $200 \mathrm{~m}$ depth at E-1 and E-3 and to a lesser extent at E-4E and E-5 (Fig. 5). Ratios estimated from ISP show very good agreement with trap $\mathrm{C}$ : Th ratios at E-3 and E-5 but not at E-1. The trap C: Th ratio at E-1 was highly variable $\left(8.6 \pm 3.9 \mu \mathrm{mol} \mathrm{dpm}^{-1}\right)$ and appears closer to
$\mathrm{C}$ : Th ratios of small $(1-53 \mu \mathrm{m})$ particles, suggesting a potential contribution of these particles to the overall export. A decreasing $C$ : Th ratio results in lower EP200 compared with EP100. However, a comparison with the HNLC reference station reveals between 2.9- and 4.5-fold higher carbon fluxes in the PF meander at $200 \mathrm{~m}$ depth. This suggests a strong impact of Fe fertilization in this area which is subjected to low-to-moderate dFe inputs. The impact of Fe fertilization on carbon export at this location is higher compared to the KEOPS1 study over the plateau ( $\sim 2$-fold higher POC flux) (Savoye et al., 2008).

High export in the PF meander remains relatively unexpected considering the temporal variation of surface phytoplankton community structure. Initially dominated by small particles including small centric and pennate diatoms, the larger phytoplankton fraction increased progressively and became dominant by the end of the time series (E-5) (Trull et al., 2015). This variability is also observed in ${ }^{234} \mathrm{Th}_{\mathrm{p}}$ and POC partitioning between the surface and $150 \mathrm{~m}$ depth. At E1, E-3, and E-4E, small particles represent the dominant fraction of ${ }^{234} \mathrm{Th}_{\mathrm{p}}$ and POC, $60-80 \%$, while at E-5 small particles fraction decreases to $50 \%$. This suggests an increasing potential for export, whereas EP tends to decrease with time. The same feature is observed for C (Cavagna et al., 2014) and Si uptake rates (Closset et al., 2014) showing low productivity at the beginning increasing progressively during the course of the survey. These inverse temporal variations between export and production are supported further by the ThE and EP/NP ratios at $100 \mathrm{~m}$ depth, where high values were observed initially (27 and $34 \%$, respectively) at E-1 decreasing progressively until E-5 (10 and 14\%, respectively). The reason for this decoupling may be numerous and highlights the complexity of export processes that cannot be easily resolved based only on primary and new production variability. One hypothesis involves food web interactions through grazing pressure, since fecal material is one of the main carriers of the POC export in the upper $200 \mathrm{~m}$ at the E stations (Laurenceau-Cornec et al., 2015a).

The early bloom export in the PF meander can be compared to the late summer situation reported for station A11 during KEOPS1 located in similar deep waters east of the Kerguelen Islands (Savoye et al., 2008). POC flux at A11 in late summer (range of $19.4-26.3 \mathrm{mmol} \mathrm{m}^{-2} \mathrm{~d}^{-1}$ ) is substantially higher than EP100 (range of 5.4-11.6 $\mathrm{mmol} \mathrm{m}^{-2} \mathrm{~d}^{-1}$ ) and EP200 (5.3-7.7 $\left.\mathrm{mmol} \mathrm{m}^{-2} \mathrm{~d}^{-1}\right)$ at E stations confirming that an important fraction of the seasonal export was not sampled during KEOPS2. At A11, the $\mathrm{C}$ : Th ratio was $11.0 \pm 1.2$ and $6.3 \mu \mathrm{mol} \mathrm{dpm}^{-1}$ at 100 and $200 \mathrm{~m}$ depth, respectively, and appears very close to the $\mathrm{C}$ : Th ratios measured at E-1 and E-3, and higher than the ratios measured at E-4E and E-5. 


\section{Conclusions}

In the present study, we investigated upper-ocean carbon export production in the naturally Fe-fertilized area adjacent to the Kerguelen Islands as part of the KEOPS2 expedition. Spatial and temporal variations in water column total ${ }^{234} \mathrm{Th}$ activity combined with the $\mathrm{C}$ : Th ratios of large potentially sinking particles were used to infer carbon export between 100 and $200 \mathrm{~m}$ depth. Export production in the Fe-fertilized area reveals large spatial variability during the early stages of bloom development with low export found at high productivity sites located over the central plateau (A3 site) and north of the PF in deep water downstream of the islands (F-L site). The highest export was observed south of the permanent meander of the PF (E stations), where a detailed time series was obtained as part of a pseudo-Lagrangian study. The comparison with the HNLC reference station located south of the PF and upstream of the islands indicates that Fe fertilization increased carbon export in all iron-fertilized waters during the early stage of the Kerguelen bloom but at variable degrees. The increase is particularly significant inside the PF meander, but more moderate over the central Kerguelen Plateau and in the northern plume of the Kerguelen bloom. Export efficiencies were particularly low at high productivity sites over and off the plateau (A3 and F-L sites) and clearly indicate that biomass was in accumulation phase rather than in export phase. The varied response of ecosystems to natural iron inputs results in varied phytoplankton community size structures, which in turn impacts the potential for carbon export. Accordingly, station A3 over the central plateau showing high biomass dominated by large diatoms may offer higher potential for carbon export compared to F-L and E sites. Comparison with late summer POC export obtained during KEOPS1 reveals a much smaller carbon export during the early stages of the bloom in spring than in late summer.

\section{The Supplement related to this article is available online} at doi:10.5194/bg-12-3831-2015-supplement.

Acknowledgements. We are grateful to KEOPS2 chief scientists Stéphane Blain and Bernard Quéguiner, and to the captain and crew of R/V Marion Dufresne for their assistance and help during the cruise. This research was supported by the French National Research Agency (grant no. ANR-10-BLAN-0614), the LEFE-CYBER program of Institut des Sciences de l'Univers (INSU), Institut Paul Emile Victor. Financial support was obtained from Belgian Science Policy (BELSPO, grant SD/CA/05A), Flanders Research Foundation (FWO, grant G071512N), Vrije Universiteit Brussel (Strategic Research Plan), the Antarctic Climate and Ecosystem Cooperative Research Centre (ACE-CRC, Hobart, Australia). We are very grateful to Michael Korntheuer for state-of-the-art beta counter maintenance, and Jacques Navez and Laurence Monin for helpful laboratory assistance. We would like to thank Lionel Scouarnec, Anne Royer, and Fabien Perault from the Technical Division of INSU in Brest for their assistance during the cruise.

Edited by: S. Blain

\section{References}

Alderkamp, A.-C., Mills, M. M., van Dijken, G. L., Laan, P., Thuróczy, C.-E., Gerringa, L. J. A., de Baar, H. J. W., Payne, C. D., Visser, R. J. W., Buma, A. G. J., and Arrigo, K. R.: Iron from melting glaciers fuels phytoplankton blooms in the Amundsen Sea (Southern Ocean): Phytoplankton characteristics and productivity, Deep-Sea Res. Pt. II, 71-76, 32-48, 2012.

Blain, S., Queguiner, B., Armand, L., Belviso, S., Bombled, B., Bopp, L., Bowie, A., Brunet, C., Brussaard, C., Carlotti, F., Christaki, U., Corbiere, A., Durand, I., Ebersbach, F., Fuda, J.L., Garcia, N., Gerringa, L., Griffiths, B., Guigue, C., Guillerm, C., Jacquet, S., Jeandel, C., Laan, P., Lefevre, D., Lo Monaco, C., Malits, A., Mosseri, J., Obernosterer, I., Park, Y.-H., Picheral, M., Pondaven, P., Remenyi, T., Sandroni, V., Sarthou, G., Savoye, N., Scouarnec, L., Souhaut, M., Thuiller, D., Timmermans, K., Trull, T., Uitz, J., van Beek, P., Veldhuis, M., Vincent, D., Viollier, E., Vong, L., and Wagener, T.: Effect of natural iron fertilization on carbon sequestration in the Southern Ocean, Nature, 446, 1070 1074, 2007.

Blain, S., Sarthou, G., and Laan, P.: Distribution of dissolved iron during the natural iron-fertilization experiment KEOPS (Kerguelen Plateau, Southern Ocean), Deep-Sea Res. Pt. II, 55, 594-605, 2008.

Blain, S., Capparos, J., Guéneuguès, A., Obernosterer, I., and Oriol, L.: Distributions and stoichiometry of dissolved nitrogen and phosphorus in the iron-fertilized region near Kerguelen (Southern Ocean), Biogeosciences, 12, 623-635, doi:10.5194/bg-12623-2015, 2015

Borrione, I. and Schlitzer, R.: Distribution and recurrence of phytoplankton blooms around South Georgia, Southern Ocean, Biogeosciences, 10, 217-231, doi:10.5194/bg-10-217-2013, 2013.

Bowie, A. R., Townsend, A. T., Lannuzel, D., Remenyi, T. A., and van der Merwe, P.: Modern sampling and analytical methods for the determination of trace elements in marine particulate material using magnetic sector inductively coupled plasma-mass spectrometry, Anal. Chim. Ac., 676, 15-27, 2010.

Bowie, A. R., van der Merwe, P., Quéroué, F., Trull, T., Fourquez, M., Planchon, F., Sarthou, G., Chever, F., Townsend, A. T., Obernosterer, I., Sallée, J. B., and Blain, S.: Iron budgets for three distinct biogeochemical sites around the Kerguelen archipelago (Southern Ocean) during the natural fertilisation experiment KEOPS-2, Biogeosciences, in review, 2015.

Boyd, P. W., Watson, A. J., Law, C. S., Abraham, E. R., Trull, T., Murdoch, R., Bakker, D. C. E., Bowie, A. R., Buesseler, K. O., Chang, H., Charette, M., Croot, P., Downing, K., Frew, R., Gall, M., Hadfield, M., Hall, J., Harvey, M., Jameson, G., LaRoche, J., Liddicoat, M., Ling, R., Maldonado, M. T., McKay, R. M., Nodder, S., Pickmere, S., Pridmore, R., Rintoul, S., Safi, K., Sutton, P., Strzepek, R., Tanneberger, K., Turner, S., Waite, A., and Zeldis, J.: A mesoscale phytoplankton bloom in the polar South- 
ern Ocean stimulated by iron fertilization, Nature, 407, 695-702, 2000.

Boyd, P. W., Jickells, T., Law, C. S., Blain, S., Boyle, E. A., Buesseler, K. O., Coale, K. H., Cullen, J. J., de Baar, H. J. W., Follows, M., Harvey, M., Lancelot, C., Levasseur, M., Owens, N. P. J., Pollard, R., Rivkin, R. B., Sarmiento, J., Schoemann, V., Smetacek, V., Takeda, S., Tsuda, A., Turner, S., and Watson, A. J.: Mesoscale iron enrichment experiments 1993-2005: Synthesis and future directions, Science, 315, 612-617, 2007.

Buesseler, K., Andrews, J., Pike, S., and Charette, M.: The Effects of Iron Fertilization on Carbon Sequestration in the Southern Ocean, Science, 304, 414-417, 2004.

Buesseler, K., Andrews, J., Pike, S. M., Charette, M. A., Goldson, L. E., Brzezinski, M. A., and Lance, V. P.: Particle export during the Southern Ocean Iron Experiment (SOFeX), Limnol. Oceanogr., 50, 311-327, 2005.

Buesseler, K. O.: The decoupling of production and particulate export in the surface ocean, Global Biogeochem. Cy., 12, 297-310, 1998.

Buesseler, K. O., Bacon, M. P., Kirk Cochran, J., and Livingston, H. D.: Carbon and nitrogen export during the JGOFS North Atlantic Bloom experiment estimated from ${ }^{234} \mathrm{Th}:{ }^{238} \mathrm{U}$ disequilibria, Deep-Sea Res. Pt. A, 39, 1115-1137, 1992.

Buesseler, K. O., Ball, L., Andrews, J., Cochran, J. K., Hirschberg, D. J., Bacon, M. P., Fleer, A., and Brzezinski, M.: Upper ocean export of particulate organic carbon and biogenic silica in the Southern Ocean along $170^{\circ} \mathrm{W}$, Deep-Sea Res. Pt. II, 48, 42754297, 2001.

Buesseler, K. O., Barber, R. T., Dickson, M.-L., Hiscock, M. R., Moore, J. K., and Sambrotto, R.: The effect of marginal ice-edge dynamics on production and export in the Southern Ocean along $170^{\circ}$ W, Deep-Sea Res. Pt. II, 50, 579-603, 2003.

Buesseler, K. O., Benitez-Nelson, C. R., Moran, S. B., Burd, A., Charette, M., Cochran, J. K., Coppola, L., Fisher, N. S., Fowler, S. W., Gardner, W. D., Guo, L. D., Gustafsson, Ã., Lamborg, C., Masque, P., Miquel, J. C., Passow, U., Santschi, P. H., Savoye, N., Stewart, G., and Trull, T.: An assessment of particulate organic carbon to thorium-234 ratios in the ocean and their impact on the application of ${ }^{234} \mathrm{Th}$ as a POC flux proxy, Mar. Chem., 100, 213-233, 2006.

Carlotti, F., Jouandet, M.-P., Nowaczyk, A., Harmelin-Vivien, M., Lefèvre, D., Guillou, G., Zhu, Y., and Zhou, M.: Mesozooplankton structure and functioning during the onset of the Kerguelen phytoplankton bloom during the Keops2 survey, Biogeosciences Discuss., 12, 2381-2427, doi:10.5194/bgd-12-2381-2015, 2015.

Cavagna, A. J., Fripiat, F., Elskens, M., Dehairs, F., Mangion, P., Chirurgien, L., Closset, I., Lasbleiz, M., Flores-Leiva, L., Cardinal, D., Leblanc, K., Fernandez, C., Lefèvre, D., Oriol, L., Blain, S., and Quéguiner, B.: Biological productivity regime and associated $\mathrm{N}$ cycling in the vicinity of Kerguelen Island area, Southern Ocean, Biogeosciences Discuss., 11, 18073-18104, doi:10.5194/bgd-11-18073-2014, 2014.

Christaki, U., Lefèvre, D., Georges, C., Colombet, J., Catala, P., Courties, C., Sime-Ngando, T., Blain, S., and Obernosterer, I.: Microbial food web dynamics during spring phytoplankton blooms in the naturally iron-fertilized Kerguelen area (Southern Ocean), Biogeosciences, 11, 6739-6753, doi:10.5194/bg-116739-2014, 2014.
Closset, I., Lasbleiz, M., Leblanc, K., Quéguiner, B., Cavagna, A.J., Elskens, M., Navez, J., and Cardinal, D.: Seasonal evolution of net and regenerated silica production around a natural $\mathrm{Fe}$ fertilized area in the Southern Ocean estimated with $\mathrm{Si}$ isotopic approaches, Biogeosciences, 11, 5827-5846, doi:10.5194/bg-115827-2014, 2014.

Coale, K. H., Johnson, K. S., Chavez, F. P., Buesseler, K. O., Barber, R. T., Brzezinski, M. A., Cochlan, W. P., Millero, F. J., Falkowski, P. G., Bauer, J. E., Wanninkhof, R. H., Kudela, R. M., Altabet, M. A., Hales, B. E., Takahashi, T., Landry, M. R., Bidigare, R. R., Wang, X., Chase, Z., Strutton, P. G., Friederich, G. E., Gorbunov, M. Y., Lance, V. P., Hilting, A. K., Hiscock, M. R., Demarest, M., Hiscock, W. T., Sullivan, K. F., Tanner, S. J., Gordon, R. M., Hunter, C. N., Elrod, V. A., Fitzwater, S. E., Jones, J. L., Tozzi, S., Koblizek, M., Roberts, A. E., Herndon, J., Brewster, J., Ladizinsky, N., Smith, G., Cooper, D., Timothy, D., Brown, S.L., Selph, K. E., Sheridan, C. C., Twining, B. S., and Johnson, Z. I.: Southern Ocean Iron Enrichment Experiment: Carbon Cycling in High- and Low-Si Waters, Science, 304, 408414, 2004.

Cochran, J. K. and Masqué, P.: Short-lived U / Th series radionuclides in the ocean: tracers for scavenging rates, export fluxes and particle dynamics, Uranium-Series Geochem., 52, 461-492, 2003.

Cochran, J. K., Buesseler, K. O., Bacon, M. P., Wang, H. W., Hirschberg, D. J., Ball, L., Andrews, J., Crossin, G., and Fleer, A.: Short-lived thorium isotopes $\left({ }^{234} \mathrm{Th},{ }^{228} \mathrm{Th}\right)$ as indicators of POC export and particle cycling in the Ross Sea, Southern Ocean, Deep-Sea Res. Pt. II, 47, 3451-3490, 2000.

d'Ovidio, F., Della Penna, A., Trull, T. W., Nencioli, F., Pujol, I., Rio, M. H., Park, Y.-H., Cotté, C., Zhou, M., and Blain, S.: The biogeochemical structuring role of horizontal stirring: Lagrangian perspectives on iron delivery downstream of the Kerguelen plateau, Biogeosciences Discuss., 12, 779-814, doi:10.5194/bgd-12-779-2015, 2015.

Ebersbach, F. and Trull, T. W.: Sinking particle properties from polyacrylamide gels during the KErguelen Ocean and Plateau compared Study (KEOPS): Zooplankton control of carbon export in an area of persistent natural iron inputs in the Southern Ocean, Limnol. Oceanogr. 53, 212-224, 2008.

Henson, S. A., Sanders, R., Madsen, E., Morris, P. J., Le Moigne, F., and Quartly, G. D.: A reduced estimate of the strength of the ocean's biological carbon pump, Geophys. Res. Lett., 38, L04606, doi:10.1029/2011GL046735, 2011.

Jacquet, S. H. M., Savoye, N., Dehairs, F., Strass, V. H., and Cardinal, D.: Mesopelagic carbon remineralization during the European Iron Fertilization Experiment, Global Biogeochem. Cy., 22, GB1023, doi:10.1016/j.dsr2.2007.12.038, 2008.

Jouandet, M. P., Blain, S., Metzl, N., Brunet, C., Trull, T. W., and Obernosterer, I.: A seasonal carbon budget for a naturally iron-fertilized bloom over the Kerguelen Plateau in the Southern Ocean, Deep-Sea Res. Pt. II, 55, 856-867, 2008.

Jouandet, M.-P., Jackson, G. A., Carlotti, F., Picheral, M., Stemmann, L., and Blain, S.: Rapid formation of large aggregates during the spring bloom of Kerguelen Island: observations and model comparisons, Biogeosciences, 11, 4393-4406, doi:10.5194/bg-11-4393-2014, 2014.

Joubert, W. R., Thomalla, S. J., Waldron, H. N., Lucas, M. I., Boye, M., Le Moigne, F. A. C., Planchon, F., and Speich, S.: Nitro- 
gen uptake by phytoplankton in the Atlantic sector of the Southern Ocean during late austral summer, Biogeosciences, 8, 29472959, doi:10.5194/bg-8-2947-2011, 2011.

Lasbleiz, M., Leblanc, K., Blain, S., Ras, J., Cornet-Barthaux, V., Hélias Nunige, S., and Quéguiner, B.: Pigments, elemental composition $(\mathrm{C}, \mathrm{N}, \mathrm{P}$, and $\mathrm{Si})$, and stoichiometry of particulate matter in the naturally iron fertilized region of Kerguelen in the Southern Ocean, Biogeosciences, 11, 5931-5955, doi:10.5194/bg-115931-2014, 2014.

Laurenceau-Cornec, E. C., Trull, T. W., Davies, D. M., Bray, S. G., Doran, J., Planchon, F., Carlotti, F., Jouandet, M.-P., Cavagna, A.-J., Waite, A. M., and Blain, S.: The relative importance of phytoplankton aggregates and zooplankton fecal pellets to carbon export: insights from free-drifting sediment trap deployments in naturally iron-fertilised waters near the Kerguelen Plateau, Biogeosciences, 12, 1007-1027, doi:10.5194/bg-121007-2015, 2015a.

Laurenceau-Cornec, E. C., Trull, T. W., Davies, D. M., De La Rocha, C. L., and Blain, S.: Phytoplankton morphology controls on marine snow sinking velocity, Mar. Ecol. Prog. Ser., 520, 3556, 2015b.

Le Moigne, F. A. C., Henson, S. A., Sanders, R. J., and Madsen, E.: Global database of surface ocean particulate organic carbon export fluxes diagnosed from the ${ }^{234} \mathrm{Th}$ technique, Earth Syst. Sci. Data, 5, 295-304, doi:10.5194/essd-5-295-2013, 2013.

Lucas, M., Seeyave, S., Sanders, R., Mark Moore, C., Williamson, R., and Stinchcombe, M.: Nitrogen uptake responses to a naturally Fe-fertilised phytoplankton bloom during the 2004/2005 CROZEX study, Deep-Sea Res. Pt. II, 54, 2138-2173, 2007.

Martin, J. H.: Glacial-interglacial $\mathrm{CO}_{2}$ change: The Iron Hypothesis, Paleoceanography, 5, 1-13, 1990.

Martin, J. H., Fitzwater, S. E., and Gordon, R. M.: Iron deficiency limits phytoplankton growth in Antarctic waters, Global Biogeochem. Cy., 4, 5-12, 1990.

Martin, J. H., Gordon, R. M., and Fitzwater, S. E.: The case for iron, Limnol. Oceanogr., 36, 1793-1802, 1991.

Martin, P., van der Loeff, M. R., Cassar, N., Vandromme, P., d'Ovidio, F., Stemmann, L., Rengarajan, R., Soares, M., González, H. E., Ebersbach, F., Lampitt, R. S., Sanders, R., Barnett, B. A., Smetacek, V., and Naqvi, S. W. A.: Iron fertilization enhanced net community production but not downward particle flux during the Southern Ocean iron fertilization experiment LOHAFEX, Global Biogeochem. Cy., 27, 871-881, 2013.

Mongin, M., Molina, E., and Trull, T. W.: Seasonality and scale of the Kerguelen plateau phytoplankton bloom: A remote sensing and modeling analysis of the influence of natural iron fertilization in the Southern Ocean, Deep-Sea Res. Pt. II, 55, 880-892, 2008

Moore, C. M., Mills, M. M., Arrigo, K. R., Berman-Frank, I., Bopp, L., Boyd, P. W., Galbraith, E. D., Geider, R. J., Guieu, C., Jaccard, S. L., Jickells, T. D., La Roche, J., Lenton, T. M., Mahowald, N. M., Maranon, E., Marinov, I., Moore, J. K., Nakatsuka, T., Oschlies, A., Saito, M. A., Thingstad, T. F., Tsuda, A., and Ulloa, O.: Processes and patterns of oceanic nutrient limitation, Nature Geosci., 6, 701-710, 2013.

Morris, P. J. and Charette, M. A.: A synthesis of upper ocean carbon and dissolved iron budgets for Southern Ocean natural iron fertilisation studies, Deep-Sea Res. Pt. II, 90, 147-157, 2013.
Morris, P. J., Sanders, R., Turnewitsch, R., and Thomalla, S. 234Th-derived particulate organic carbon export from an islandinduced phytoplankton bloom in the Southern Ocean, Deep-Sea Res. Pt. II, 54, 2208-2232, 2007.

Mosseri, J., Quéguiner, B., Armand, L., and Cornet-Barthaux, V.: Impact of iron on silicon utilization by diatoms in the Southern Ocean: A case study of $\mathrm{Si} / \mathrm{N}$ cycle decoupling in a naturally iron-enriched area, Deep-Sea Res. Pt. II, 55, 801-819, 2008.

Nodder, S. D., Charette, M. A., Waite, A. M., Trull, T. W., Boyd, P. W., Zeldis, J., and Buesseler, K. O.: Particle transformations and export flux during an in situ iron-stimulated algal bloom in the Southern Ocean, Geophys. Res. Lett., 28, 2409-2412, 2001.

Owens, S. A., Buesseler, K. O., and Sims, K. W. W.: Re-evaluating the ${ }^{238} \mathrm{U}$-salinity relationship in seawater: Implications for the ${ }^{238} \mathrm{U} \_{ }^{234} \mathrm{Th}$ disequilibrium method, Mar. Chem., 127, 31-39, 2011.

Park, Y.-H., Fuda, J.-L., Durand, I., and Naveira Garabato, A. C.: Internal tides and vertical mixing over the Kerguelen Plateau, Deep-Sea Res. Pt. II, 55, 582-593, 2008 a.

Park, Y.-H., Roquet, F., Durand, I., and Fuda, J.-L.: Large-scale circulation over and around the Northern Kerguelen Plateau, DeepSea Res. Pt. II, 55, 566-581, 2008b.

Park, Y.-H., Durand, I., Kestenare, E., Rougier, G., Zhou, M., d'Ovidio, F., Cotté, C., and Lee, J.-H.: Polar Front around the Kerguelen Islands: An up-to-date determination and associated circulation of surface/subsurface waters, J. Geophys. Res.Oceans, 119, 6575-6592, 2014a.

Park, Y.-H., Lee, J.-H., Durand, I., and Hong, C.-S.: Validation of Thorpe-scale-derived vertical diffusivities against microstructure measurements in the Kerguelen region, Biogeosciences, 11, 6927-6937, doi:10.5194/bg-11-6927-2014, 2014b.

Pike, S. M., Buesseler, K. O., Andrews, J., and Savoye, N.: Quantification of 234Th recovery in small volume sea water samples by inductively coupled plasma-mass spectrometry, J. Radioanal. Nucl. Chem., 263, 355-360, 2005.

Planchon, F., Cavagna, A.-J., Cardinal, D., André, L., and Dehairs, F.: Late summer particulate organic carbon export and twilight zone remineralisation in the Atlantic sector of the Southern Ocean, Biogeosciences, 10, 803-820, doi:10.5194/bg-10-8032013, 2013.

Planquette, H., Statham, P. J., Fones, G. R., Charette, M. A., Moore, C. M., Salter, I., Nédélec, F. H., Taylor, S. L., French, M., Baker, A. R., Mahowald, N., and Jickells, T. D.: Dissolved iron in the vicinity of the Crozet Islands, Southern Ocean, Deep-Sea Res. Pt. II, 54, 1999-2019, 2007.

Pollard, R. T., Salter, I., Sanders, R. J., Lucas, M. I., Moore, C. M., Mills, R. A., Statham, P. J., Allen, J. T., Baker, A. R., Bakker, D. C. E., Charette, M. A., Fielding, S., Fones, G. R., French, M., Hickman, A. E., Holland, R. J., Hughes, J. A., Jickells, T. D., Lampitt, R. S., Morris, P. J., Nedelec, F. H., Nielsdottir, M., Planquette, H., Popova, E. E., Poulton, A. J., Read, J. F., Seeyave, S., Smith, T., Stinchcombe, M., Taylor, S., Thomalla, S., Venables, H. J., Williamson, R., and Zubkov, M. V.: Southern Ocean deep-water carbon export enhanced by natural iron fertilization, Nature, 457, 577-580, 2009.

Quéroué, F., Sarthou, G., Planquette, H. F., Bucciarelli, E., Chever, F., van der Merwe, P., Lannuzel, D., Townsend, A. T., Cheize, M., Blain, S., d'Ovidio, F., and Bowie, A. R.: High variability of dissolved iron concentrations in the vicinity of Kerguelen Is- 
land (Southern Ocean), Biogeosciences Discuss., 12, 231-270, doi:10.5194/bgd-12-231-2015, 2015.

Rutgers van der Loeff, M. M., Friedrich, J., and Bathmann, U. V.: Carbon export during the Spring Bloom at the Antarctic Polar Front, determined with the natural tracer ${ }^{234} \mathrm{Th}$, Deep-Sea Res. Pt. II, 44, 457-478, 1997.

Rutgers van der Loeff, M., Cai, P. H., Stimac, I., Bracher, A., Middag, R., Klunder, M. B., and van Heuven, S. M. A. C.: ${ }^{234}$ Th in surface waters: distribution of particle export flux across the Antarctic Circumpolar Current and in the Weddell Sea during the GEOTRACES expedition ZERO and DRAKE, Deep-Sea Res. Pt. II, 58, 2749-2766, 2011.

Salter, I., Lampitt, R. S., Sanders, R., Poulton, A., Kemp, A. E. S., Boorman, B., Saw, K., and Pearce, R.: Estimating carbon, silica and diatom export from a naturally fertilised phytoplankton bloom in the Southern Ocean using PELAGRA: A novel drifting sediment trap, Deep-Sea Res. Pt. II, 54, 2233-2259, 2007.

Sambrotto, R. N. and Mace, B. J.: Coupling of biological and physical regimes across the Antarctic Polar Front as reflected by nitrogen production and recycling, Deep-Sea Res. Pt. II, 47, 33393367, 2000.

Savoye, N., Benitez-Nelson, C., Burd, A. B., Cochran, J. K., Charette, M., Buesseler, K. O., Jackson, G. A., Roy-Barman, M., Schmidt, S., and Elskens, M.: ${ }^{234}$ Th sorption and export models in the water column: A review, Mar, Chem., 100, 234-249, 2006.

Savoye, N., Trull, T. W., Jacquet, S. H. M., Navez, J., and Dehairs, F.: 234Th-based export fluxes during a natural iron fertilization experiment in the Southern Ocean (KEOPS), Deep-Sea Res. Pt. II, 55, 841-855, 2008.

Sedwick, P. N., DiTullio, G. R., Hutchins, D. A., Boyd, P. W., Griffiths, F. B., Crossley, A. C., Trull, T. W., and Quéguiner, B.: Limitation of algal growth by iron deficiency in the Australian Subantarctic Region, Geophys. Res. Lett., 26, 2865-2868, 1999.
Seeyave, S., Lucas, M.I., Moore, C. M., and Poulton, A. J.: Phytoplankton productivity and community structure in the vicinity of the Crozet Plateau during austral summer 2004/2005, Deep-Sea Res. Pt. II, 54, 2020-2044, 2007.

Smetacek, V., Klaas, C., Strass, V. H., Assmy, P., Montresor, M., Cisewski, B., Savoye, N., Webb, A., d'Ovidio, F., Arrieta, J. M., Bathmann, U., Bellerby, R., Berg, G. M., Croot, P., Gonzalez, S., Henjes, J., Herndl, G. J., Hoffmann, L. J., Leach, H., Losch, M., Mills, M. M., Neill, C., Peeken, I., Rottgers, R., Sachs, O., Sauter, E., Schmidt, M. M., Schwarz, J., Terbruggen, A., and Wolf-Gladrow, D.: Deep carbon export from a Southern Ocean iron-fertilized diatom bloom, Nature, 487, 313-319, 2012.

Trull, T. W., Davies, D. M., Dehairs, F., Cavagna, A.-J., Lasbleiz, M., Laurenceau-Cornec, E. C., d'Ovidio, F., Planchon, F., Leblanc, K., Quéguiner, B., and Blain, S.: Chemometric perspectives on plankton community responses to natural iron fertilisation over and downstream of the Kerguelen Plateau in the Southern Ocean, Biogeosciences, 12, 1029-1056, doi:10.5194/bg-121029-2015, 2015.

van der Merwe, P., Bowie, A. R., Quéroué, F., Armand, L., Blain, S., Chever, F., Davies, D., Dehairs, F., Planchon, F., Sarthou, G., Townsend, A. T., and Trull, T. W.: Sourcing the iron in the naturally fertilised bloom around the Kerguelen Plateau: particulate trace metal dynamics, Biogeosciences, 12, 739-755, doi:10.5194/bg-12-739-2015, 2015.

Zhou, M., Zhu, Y., Measures, C.I., Hatta, M., Charette, M.A., Gille, S.T., Frants, M., Jiang, M., and Greg Mitchell, B.: Winter mesoscale circulation on the shelf slope region of the southern Drake Passage, Deep-Sea Res. Pt. II, 90, 4-14, 2013. 